\title{
Avrupa İşci Sendikaları Konfederasyonunun (ETUC) Küreselleşme Bağlamında Değerlendirilmesi
}

\section{Evaluation of the European Trade Union Confederation (ETUC) in the Context of Globalization}

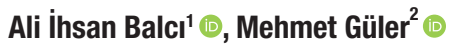

\section{Öz}

Küreselleşme süreci ülkelere ekonomik, siyasal ve sosyal alanlarda değişim ve dönüşüm yaşatmış ve yaşatmaktadır. Ülkelerin sosyal politikaları ve çalışma ilişkileri kurumları da küreselleşmenin yaşatmış olduğu bu dönüşümden fazlasıyla etkilenmektedir. Küreselleşme süreci ile birlikte ortaya çıkan yeni üretim ve yönetim teknikleri sebebiyle endüstri ilişkilerinin en önemli aktörlerinden biri olan sendikalar için olumsuz bir ortam oluşmuştur. Nitekim süreçte etkinliği artan çok uluslu şirketlerin artık yerel olarak örgütlenmektense uluslar üstü örgütlenmeye gittikleri görülmektedir.

Sendikaların en önemli gücü olan toplu ses mekanizması ve küresel boyutta örgütlenme istekleri sanayi devriminin yaşandığı yıllardan beri mevcuttur. Fakat günümüzde sendikaların bu isteklerini sadece küresel düzeyde bir üst örgüt çatısı altında örgütlenmekle sınılı olarak gerçekleştirdiklerini söylemek mümkündür. Küresel üst sendikal örgütler sadece çalışma hayatındaki işçi ve işveren arasındaki sorunlarla ilgilenmenin yanı sıra toplumsal hayattaki diğer dezavantajlı grupların sorunlarına da odaklanmaktadır.

Bu çalışmanın temel amacı ETUC'un küreselleşme sürecindeki dönüşümünü incelemektir. Küreselleşme sürecinde ETUC'da çeşitli değişim ve dönüşümler geçirmiştir. ETUC'un amacı Avrupa düzeyindeki işçi hareketlerinin koordine olmasını sağlamak ve bu iş̧̧i hareketlerini tek bir çatı altında örgütlemektir. Bu amacını sürdürürken bölgesel bir güç olma etkinliğini de sürdürmektedir. Bu çalışmada ETUC'un küreselleşme sürecinde geçirmiş olduğu değişimler aktarılarak, günümüzde ETUC'un örgütlenme stratejisi irdelenecektir.

\section{Anahtar Kelimeler}

Avrupa İş̧i Sendikaları Konfederasyonu (ETUC), Küreselleşme ve Sendika

1 Sorumlu Yazar: Ali İhsan Balcı (Arş. Gör.), İstanbul Üniversitesi, İktisat Fakültesi, Çalışma Ekonomisi ve Endüstri İlişkileri Bölümü, İstanbul, Türkiye. E-posta: abalci@istanbul.edu.tr ORCID: 0000-0002-9695-732X

2 Mehmet Güler (Dr. Öğr. Üyesi,), İstanbul Üniversitesi, İktisat Fakültesi, Çalışma Ekonomisi ve Endüstri İlişkileri Bölümü, İstanbul, Türkiye. E-posta: mehmetguler@istanbul.edu.tr ORCID: 0000-0002-2956-7604

Atıf: Balci, A. I. ve Guler, M. (2019). Avrupa işçi sendikaları konfederasyonunun (ETUC) küreselleşme bağlamında değerlendirilmesi. Sosyal Siyaset Konferansları Dergisi, 77: 383-420. https://doi.org/10.26650/jspc.2019.77.0099 


\begin{abstract}
The process of globalization has and has given countries change and transformation in economic, political and social fields.The social policies and labor relations institutions of the countries are also affected by this transformation of globalization. Due to the new production and management techniques that emerged with the globalization process, a negative environment emerged for the trade unions, one of the most important actors in industrial relations. As a matter of fact, it is seen that the multinational companies whose effectiveness is increasing in the process are now going to transnational organization rather than being organized locally.

The collective voice mechanism, which is the most important power of the unions, and the aspirations to organize on a global scale have existed since the years of the industrial revolution. However, it is possible to say that today, unions have fulfilled these demands only by being organized under the umbrella of a higher organization on a global level. Global top trade union organizations focus not only on the problems between workers and employers in working life, but also on the problems of other disadvantaged groups in social life.

The main purpose of this study is to examine the role of the ETUC in the European Union. During the globalization process, ETUC has undergone various changes and transformations. The aim of the ETUC is to ensure the coordination of workers 'movements at European level and to organize these workers' movements under one roof. While maintaining this aim, it continues to be a regional power. In this study, the changes of the ETUC in the globalization process will be discussed and the organization strategy of ETUC will be tried to be determined.
\end{abstract}

\title{
Keywords
}

Evaluation of the European Union Confederation (ETUC), Globalization and Trade Union 


\section{Extended Summary}

The process of globalization increases its impact on societies. While this situation is criticized by some academics that economies, culturally and politically, countries and institutions are moving away from their essence, it is considered by some academics as a valuable process that makes it necessary to become a global village which is an important integration required by today's conditions. Globalization is a process that increases the competition among countries in line with the capitalist tendency in the world, directs societies to consumption, offers great advantages for developed countries, but provides an unfair environment under competition conditions for developing and underdeveloped countries. In other words, the process of globalization is a concept used to express a dynamic process that presents all positive and negative aspects for countries.

The economic policies of the countries and institutions started to change in a more liberal direction due to the dominance of the liberal view that advocated the necessity of economic opening to the world, especially after the 1980s. This has undoubtedly affected individuals and institutions involved in labor relations in the country. For example, in the periods when globalization and openness were not so effective, in the periods when Keynesian economic policies were applied, unions in the countries were in a much stronger and collective unity in forming a single whole, a single voice; indirectly, the unions have a tendency to decline. Multinational companies are expressed as the locomotive force of the globalization process. From another perspective, this can be read as employers wanting to dominate labor markets on a global scale. Therefore, the struggle against the globally organized employers has brought a very challenging process for the local unions. Because, employers who are organized on a global scale have been able to intervene in working conditions even in the most remote parts of the world through multinational companies and in other words, they can easily reach the places where there are some better but cheaper labor conditions in the industrial revolution. Through multinational corporations, global production chains were established in the Far East, Africa and South America, where cheap labor was established, and they entered the non-union labor markets and quickly separated from the labor markets of developing countries in Europe and in particular with protective laws. Thus, the economies of these countries have experienced turbulence and have tried to attract foreign capital to their countries especially with the flexible regulations 
they apply in their laws. The interventions of multinational corporations in various ways and in an unfair order in various countries have brought forward the idea of making arrangements that can be valid for the workers in terms of working conditions, occupational health and safety. However, in order to defend this view, it is essential that the unions organized at the local level unite and organize at the global and regional level. The idea of unification of labor organizations is actually based on the First International in the 1860 s before the $1980 \mathrm{~s}$, which is considered the beginning of the globalization process. It was argued in the internationalities that the global working class should be united and a global labor union should be established. Therefore, it is important to establish a standard order against labor and to organize it on a global level. Thus, it has become even more important that globalization should be organized on a global scale in the trade unions against the global power given to the employer. The existence of a globally organized union will ensure that the labor side is strong in regional and global terms. While the whole world has undergone a significant transformation with the globalization process, a union initiative has been experienced in Europe as well. The face of this initiative as an institution is the ETUC (European Trade Union Confederation). The single market idea of employers in Europe has had a major impact on working conditions and social policies. At this point, the European ETUC has become an important social partner among these social policy-makers and contributed greatly to the European Social Dialogue. Therefore, the fact that it has an important place in the European social dialogue as an important actor has continued to work at a higher level than the local unions.

ITUC (International Trade Union Confederation) is the leading force of global trade unionism. ITUC and ETUC are very similar in terms of organization and intellectual thinking, and moreover, they can be expressed as reflections of each other in global and regional dimensions. Therefore, the fact that ETUC and ITUC have a very important place in terms of the idea of global unionism has played an important role in the formation of research questions in this study. As a matter of fact, it was started with the desire to examine the place and importance of ETUC in the European Union. The ETUC is no doubt a global organization large enough to respond to globalization. However, it is a very important organization in terms of the regional top representation. Recognizing the lack of studies on ETUC and ITUC in the Turkish literature is also important in terms of partially filling the gap in this area and guiding future studies. 


\section{Avrupa İşçi Sendikaları Konfederasyonunun (ETUC) Küreselleşme Bağlamında Değerlendirilmesi}

Küreselleşme süreci ile birlikte uygulama alanı genişlemiş olan neo-liberal politikalar toplumsal alanda yoksulluk, gelir dağılımında adaletsizlik, sosyal dışlanma, işsizlik, göç, çevre, kayıt dışı istihdam ve kadın işçi sorunları gibi pek çok sorunu beraberinde getirmiştir.

Küreselleşmenin Endüstri ilişkileri sisteminin aktörlerine etkisi ise; ulus devletin küçültülmesi, sendikaların ya tamamen sistemden çekilmesi ya da mücadeleci politikalar yerine paydaş politikalar izlemeye zorlanması şeklinde kendini göstermiştir. Bölgesel anlamda güçleri daralan sendikalar uluslararası sendikal örgütlerin öncülüğünde bu sorunları çözmeye uğraşırken bir yandan da eski güç ve etkinliklerini kazanmaya çalışmaktadır.

Sendikalar sosyal politika alanının şekillenmesinde oldukça önemli ve kritik bir role sahiptir. Fakat küreselleşmenin getirdiği ortam sendikaların sosyal politikalara olan etki alanını da daraltmaktadır. Başka bir ifadeyle küreselleşme süreci ile birlikte rekabet şartlarının artması, ulusal sınırların ortadan kalkması ve uluslararası şirketlerin de etkisi ile sosyal politikaların belirlenmesinde endüstri ilişkilerinin aktörlerinin karar alma mekanizmalarındaki güç dengesi değişmiştir. Süreç ulus devletlerin güçlerini azaltmış işçilerin daha zorlu şartlar altında rekabet etmesine, işçi örgütlerinin yapısal dönüşümler geçirmesine neden olmuştur. Buna bağlı olarak hem işçiler hem de işverenler yeni örgütlenme şekilleri arayışına girmişlerdir. İşverenlerin küresel çapta örgütlenmeleri ve insan kaynakları politikaları karşısında işçiler ve sendikalar daha zorlu şartlarla karşılaşmış ve daha fazla baskıya maruz kalmışlardır. Bu baskılarla mücadele edebilmek için de küresel düzeyde örgütlenme gereksinimi duymuşlardır. Zira küresel baskılara karşı küresel düzeyde örgütlenme, sendikalara, ses mekanizmalarını daha etkili kullanabilme imkanı sunmaktadır.

Sendikaların uluslararası düzeyde örgütlenme istekleri küreselleşmenin zorlayıcı etkilerinin ortaya çıkmasından daha erken tarihlerde görülmektedir. Nitekim ulusal sendikaların birleşip çalışma hayatı ile ilgili düzenlemeler yapma çabası olarak bilinen ve enternasyonalizm olarak da adlandırılan kavram bunun bir örneğidir. Fakat enternasyonalizmden ayrılan bu durum, küresel sendikacılık, küreselleşmenin getirdiği (yoksulluk, adaletsizlik, ayrımcılık, işsizlik, dışlanma vb.) sorunları da içeren ve sendikaların örgütlenme tecrübelerinden de 
yararlanarak sendikalara daha güçlü mücadele edebilme imkanı sunmaktadır. Küresel sendikacılık olarak da adlandırılabilecek bu yapı için en önemli örgüt ise küresel bir güç olan "Uluslararası İşçi Sendikası Konfederasyonu (ITUC)" olarak göze çarpmaktadır.

$\mathrm{Bu}$ çalışmanın da temel amacı ITUC'un Avrupa uzantısı olarak da adlandırabileceğimiz bölgesel aktör olan “Avrupa İşçi Sendikaları Konfederasyonunun (ETUC)” Avrupa Birliği düzeyinde rolünü incelemektir. Bu araştırmada ETUC'un tercih edilme sebebi 39 Avrupa ülkesinde 89 sendikanın üyesi olduğu (DİSK, Türk-İş, Hak-iş ve KESK dahil) yaklaşık 45 milyon üyeyi temsil eden önemli bir örgüt olmasıdır. Avrupalı işçilerin sesi olmayı hedefleyen ETUC son dönemde sadece çalışma hayatı ile ilgili sorunları değil aynı zamanda küreselleşmenin ortaya çıkardığı diğer sorunlarla da ilgilenmektedir.

Küreselleşme sürecinde toplumlar ekonomik, sosyal ve siyasal değişimler yaşamıştır. Bu süreçten belki de en çok etkilenen sanayi toplumunun kendine has özelliklerine dayalı olarak varlığını sürdüren kurumlar olmuştur. ETUC da küreselleşme sürecinin ortaya çıkardığı yeni toplumsal modelin gereklerine uyumlu bir şekilde hem yapısal hem de benimsediği strateji olarak değişimler geçirmiştir. ETUC ilk olarak Avrupa çapındaki işçilerin ve işçi hareketlerinin sadece bir kısmı için şemsiye bir örgüt olmaktan Avrupa Birliği düzeyinde karar alma mekanizmalarını etkileyebilen güçlü bir aktör olma rolüne doğru bir eğilim göstermiştir. Bu da ETUC'un ilk başlarda klasik mücadeleye dayal, örgütlenme esaslı bir sendikacılık felsefesinden, kurumlarla ilişkilerini sağlamlaştıracak, karar alma mekanizmalarında üyelerinin çıkarlarını tek başına koruyacak ve ilişkili olduğu kurumları etkileyebilmek adına paydaş bir felsefeye doğru yönelmiştir.

Ulusal sendikalar için yaşanan bu gelişmeler geleneksel eylem politikalarını zayıflatmış ve üst düzeyde temsil kapasitesi olan şemsiye örgütlere olan bağımlılıkları artmıştır. Hiç şüphesiz Avrupa için en önemli üst örgüt ETUC'dur. ETUC son yıllarda Avrupa Birliği ilişkileri hiyerarşisinde giderek önem kazanırken ETUC'un temsil etme, benimsediği stratejiler ve politika oluşturma süreçleri kısacası yapısı hakkında oldukça az akademik çalışmanın olması şaşırtıcıdır.

Bu çalışmada ETUC'un yaşadığı felsefi değişim incelenmek istenmektedir. Dolayısı ile çalışmanın ilk bölümünde küreselleşme ve küreselleşme sürecinin getirdiği olumsuzluklara karşı sendikaların tepkisi anlatılacaktır. 
İkinci bölümde ise ETUC'un yapısı ve yaşamış olduğu stratejik değişim süreçleri incelenecektir.

\section{Küreselleşme ve Sendikalar}

\section{Küreselleşmenin Karakteristik Özellikleri}

Küresel krizin çıkar yolu olarak uluslararası sermayenin teşviki, altyapı hizmetleri, finansman ve ortaklık düzenlemelerinin sağlanması oldukça önemli görülmektedir. Başka bir ifade ile ulus devletler tek başlarına krizin üstesinden gelebilmek için gerekli araçlara sahip değildir (Barchiesi, 2001, s. 386).

Kısaca küreselleşmenin karakteristik özellikleri başlığı altında tartışılan ve vurgulanmak istenen, küreselleşme kapitalizmin zaman mekan arasındaki dönüşümü ile ülkeler arası mesafeleri önemsiz hale getirmesi sonucunda dönüşümün merkezinde yaşanan sosyal ve ekonomik durumlar işçiler ve sendikalar için önemli gelişmeler ortaya çıkarmaktadır. Ancak bu gelişmeler karşısında tedbir alınmadığı takdirde sonuçlarının daha büyük olumsuzluklar ortaya çıkarması muhtemeldir.

\section{Küreselleşme Süreci ve Sendikal Hareketin Küreselleşme Karşısında Yenlik Arayışları}

Küreselleşme süreci her geçen gün ulus devletlerin ekonomisini birbirine bağl1 ve bağımlı bir hale getirmektedir. Üretimin işgücü maliyetlerinin daha düşük olduğu bir ülkeden veya bölgeden diğerine geçmesi artık daha kolay, hızlı ve sık gerçekleşmektedir. Buna bağlı olarak uluslararası kuruluşlar devletlerin uluslararası ekonomi politikaları oluşturmadaki rolünü ele geçirmekte ve daha etkili bir hale gelmektedir. Başka bir ifade ile küreselleşme süreci ulus devletlerinin gittikçe zayıflamasına ve geri planda kalmasına sebep olmaktadır. Kısaca ulusal sınırların ortadan kalkması ile birlikte sermayenin hareket kabiliyetinin artması işletmeleri bir ülkeye bağımlı olmaktan uzaklaştırmıştır (Castells, 2010, s. 476). Böylece rekabet, ulusal ve bölgesel düzeyden uluslararası ve küresel düzeye genişlemiştir. Aynı zamanda klasik çalışma ilişkileri değişime uğramış hizmet, finans ve teknoloji ağırlıklı sektörler sanayi sektörünün yerini almıştır. Her ne kadar üzerinde uzlaşmaya varılmış bir tanım yapılması mümkün olmasa da ekonomik, siyasi ve sosyal alanda pek çok etki bırakan ve özellikle endüstri ilişkilerini değişime/dönüşüme zorlayan süreç için küreselleşme tanımı kullanılmaktadır (Erdut, 2002, s. 1-18). 
Değişim ve dönüşümün oldukça hızlı bir şekilde gerçekleştiği günümüz dünyasında ortaya çıkan “dünya kapitalizmi, post-modern dönem, global bilinç, network toplumu” gibi terimler küresel sistemin özelliklerini ifade etmek için kullanılmaktadır (Robinson, 2009, s. 5-6). Bu yeni sistem gelişmekte olan ülkelerde yeni iş bölümleri, kayıt dışılık, savunmasız ve örgütlenmemiş sektörlerde emek yoğun üretimin yapıldığı bir düzen içinde gelişmiş ülkelerin ekonomilerine büyük avantajlar sağlarken; üretimin yapıldığı gelişmekte olan ve gelişmemiş ülkelerdeki çalışma şartları, sosyal sorunlar göz ardı edilmektedir (Barchiesi, 2001, s. 386). Bu süreçte kültürden, kamu yönetimine kadar çok sayıda parametre doğal olarak değişime uğramış dünya siyaseti ve aktörler küresel bir hale gelmiştir. Ülkelerin bu derece birbirine bağımlı hale gelmesi neticesinde herhangi bir ekonomik, politik, sosyolojik, kültürel, teknolojik bir değişim küreselleşme süreci ve sonuçları ile kolaylıkla ilişsilendirilebilecek bir hal almıştır (Robertson, 2000, s. 8-12).

Küreselleşme eskiden uygulanan keskin ve katı kuralların ortadan kaldırılmasını ön gören deregülasyon eğilimlerinin artmasına neden olmuştur (Hyman R. , 2001, s. 167-168). Deregülasyonlar yani kuralların ortadan kaldırılması veya tarafların doğrudan kuralları kendileri belirlemesi, normların yerine ekonomik değer kavramına atfedilen önemi artırarak, sermayenin öneminin artmasına karşısında devletin ve işgücünün dezavantajlı bir konuma getirmiş, endüstri ilişkilerindeki aktörlerin güç dengesinin değişmesine neden olmuştur. Süreç devletin sosyal ve ekonomik politikalarındaki düzenleyici rolünün azalmasına ve giderek küçülmesini gerekli kılan bir ortam yaratmış, bu alandaki sorumluluğu da çok uluslu hatta "ulus ötesi”" şirketlere bırakmıştır (Gallin, 2000, s. 5). Sassen de bu görüşü destekleyici bir biçimde küreselleşmenin ulusal ve uluslararası aktörler arasında sınır ötesi ağların yoğunlaşmasını, bir ekonomide yaşanan krizin diğer ülkelerin ekonomilerine yansımasını örnek göstererek bu durumun küreselleşmenin en önemli özelliğin olduğunu iddia etmektedir (Sassen, 2003, s. 1-2). Schulze'da Sassen ile aynı perspektiften bakarak küreselleşme için kamu mallarının küresel aktörlere tahsis edilmesine yol açan bir süreç olduğunu ifade eder. (Schulze \& Ursprung, 1999, s. 323) Dolayısı ile aslında süreç devletin müzakere masasındaki pozisyonunun eskiye oranla oldukça zayıflattı̆g 1 ve sürecin ortaya çıkardığı yeni aktörleri devletlerin karşısında daha büyük söz sahibi konuma getirdiği şeklinde yorumlanabilir. Küreselleşmenin kurumsal tarafını ise Dünya Bankası (WB), Dünya Ticaret Örgütü (WTO), Uluslararası Para Fonu (IMF) gibi kurumlar oluşturmaktadır. Bu kurumlar küreselleşme 
sürecinde uluslararası kuralları yeniden düzenleme, yapısal uyum politikaları ve ticaretin serbestleştirilmesine vurgu yaparak yeni düzenin ulus devletleri olma yolunda ilerlemektedirler (Barchiesi, 2001, s. 385-386). Bütün bunların yanında özelleştirmeler neticesinde devletin işveren rolü de daralmıştır. Devletler özelleştirme politikalarıyla kamu mallarını satarak güçlenmeyi planlarken, ekonomik kaldıraç olma özelliklerini kaybetmeye ve böylelikle ekonomi politikalarını etkileme yeteneklerinin zayıflamasına neden olmuştur (Gallin, 2000, s. 5-6).

Gallin'in belirttiği üzere Avrupa birliği ve küreselleşen dünya sisteminin temel kurumları olan uluslararası finans kurumları birbirileri ile uyumlu olarak "kemer sıkma önlemleri” ve kamu maliyesi üzerinde daha sıkı bir kontrol talep etmektedir. Yaşanan krizlerin etkisinden kurtulmak için özellikler Avrupa hükümetleri ilk olarak ücret ve maaşlarda kesintiye gitme ve bunları etkileyen katkı paylarını ve dolaylı vergileri artırmayı çözüm olarak gördü. Bunun altında yatan temel neden ise emeğin ücretinin en kolay değiştirilebilir üretim faktörü olmasından kaynaklanmaktadır. Dahası işverenlere yönelik bir yaptırımdan ziyade işletmelerin işleyişini sürdürme ve ekonomiyi teşvik etme amaçlı çalışma koşulları bile sertleştirilmiştir. Dolayısı ile küreselleşmeye kuşku ile yaklaşanların "the race to the bottom" (aşağıda rekabet) fikrini daha belirgin bir şekilde ortaya çıkarmaktadır (Gallin, 1994, s. 111)

Sendikal hareket gücünü üye sayısının çokluğundan ve toplu pazarlıktaki etkinliğinden almaktadır. Küreselleşme süreci sendikaların gücünün üzerinde bir baskı unsuru oluşturmakta ve sendikasız endüstri ilişkileri tartışmasını gündeme getirmektedir. Bu tartışmalar ve yaşanan güç kayıplarını telafi etmek için sendikalar bir takım yenilik arayışına girmiştir. Bu arayışlarının özünde gelecekte varlıklarını ve etkinliklerini sürdürebilmek adına küreselleşmeye bir karş1 cevap verebilme, küreselleşmenin getirmiş olduğu kötü şartlardan toplumları bilinçlendirerek kurtarma içgüdüsü yer almaktadır. Özellikle 2000'li yıllardan itibaren sendikaların yeniden canlanabileceği üzerine pek çok tartışma yapıldığı görülmektedir. Bu tartışmalar sendikaların yeniden yapılanmaları için gerekli olan stratejileri, ittifakları, birleşmeleri, politikaları üzerinden yapılmaktadır (Bernaciak, Gumbrell- McCormick, \& Hyman, 2014, s. 17) (Phelan, 2007, s. 16-22) (Selamoğlu, 2003, s. 66-69) (Tokol, 2013, s. 45-50) (K1lıc, 2014) (Ross \& Martin, 1999) (Waddington \& Hoffman, 2000). Sendikaların içinde bulunan küresel saldırıdan kurtulabilmeleri için kendilerini yeniden 
tanımlamaları, diğer sivil toplum kuruluşları ile ittifak ve işbirliği yollarına gitmeleri, yeni ekonomik düzende yeniden örgütlenebilmeleri, küresel çapta mücadele etmeleri ve güçlü sendikal harekete olan ihtiyacın önemine işaret etmektedirler (Erdoğdu, 2003) (Aguition, 2005).

Sendikal hareketin bu süreçte belki de gözden kaçırdığı en önemli noktalardan birine işaret eden Munck; sendikal hareketin gelecek adına umut verici potansiyel gücünden bahsetmektedir. Munck'a göre küresel bir sendikal hareket için gerekli olan altyapı ve teknolojiye sendikalar sahiptir. İşçi hareketlerinin ilk doğuşunda enternasyonalist bir bakışın etkisinin olması gibi, günümüzde de sendikalar, emek ve diğer toplumsal hareketlerin küreselleşme karşıtı ya da yanlısı olmaktan ziyade, küreselleşmeyi bir toplumsal dönüşüm olarak okumalarını tavsiye etmektedir. Bu tavsiyesini küreselleşme sürecinde ortaya çıkan gelişmelerin çalışma hayatını bitirdiği, sendikal örgütlenmeyi sona getirdiği, işçi sınıfını ortadan kaldırdığı yönündeki söylemlerin yerine, küreselleşmenin ortaya çıkardığı üretim dünyasının merkezinde emeğin yer aldığını emek hareketinin de küreselleşme sürecinin geleceğini şekillendirebileceği yeniden yapılanmaya soktuğunu göstermektedir (Munck, 2003)

\section{Sendikaların Küreselleşmeye Karşı Mücadelesi}

Küreselleşmeye bağlı olarak gelişen faktörler sendikaların en temel gücü olan üye sayılarını azaltmaktadır. Buna karşı sendikalar işyerlerinde örgütlenme kampanyalarını yerel ve uluslararası düzeye taşıma, stratejik araştırmaya önem vererek küreselleşmeye karşı cevap vermeye çalışmaktadır. Özellikle AngloSaxon ülkelerin sendikalarının bu cevap arayışı sendikal hareketin üye kazanma sorununu tamamen ortadan kaldırmasa da, işçilerin çalışma şartlarını ve ücretlerini geliştirmiştir (Kloosterboer, 2007, s. 11). Hiç şüphesiz sendikaların yeniden canlanma stratejileri (paydaşlık, örgütlenme, politik eylem, yeniden yapılanma, uluslararası dayanışma, toplumdaki güçsüz kalan kesimlerle ittifak) içinde bulunulan durum ve ortama göre farklı başarı düzeyleri elde edecektir dolayısı ile bu stratejilerden birisini ön plana çıkarmak oldukça zordur. Genel olarak bu stratejiler gençler, kadınlar, hizmet sektörü çalışanları gibi sendikalaşma oranlarının düşük olduğu gruplar için sendikacılığa bakış anlamında pozitif bir etki yaratabilir. Aynı zamanda sosyal diyaloga önem verilip hükümetlerle ikili ilişkilerin kurulması sendikalara sıcak bakmayan politikacıların da fikirlerinde değişikliğe sebep olabilir (Kloosterboer, 2007, s. 15-17) 
Kloosterboer'e göre sendikalar sadece üyeleri için değil, bütün toplumun şekillenmesi için önemli bir yapıdır. Bu noktadan hareketle sendikalar, gelir dağ1lımında adalet, toplumun bütün kesimlerini kapsayan sosyal düzenlemeler, gerçek bir demokrasi ve istihdamın gelişmesinde önemli bir rol oynayan örgütler olarak topluma hizmet etmektedirler (Kloosterboer, 2007, s. 19-20)

Erdoğdu uluslararası sendikacılık hareketinin, bölgesel ve küresel politikalarının küreselleşme sürecinin yaygınlaşmaya başladığı yıllardan itibaren şekillendiğini, sendikaların belirlemiş olduğu bu politikalarınınsa küreselleşme sürecine bir de sosyal boyut eklediği üzerinde durmaktadır. (Erdoğdu, 2003, s. 253)

ILO küreselleşme sürecinde sendikaların vermiş olduğu tepkileri gösteren bazı çalışmalar yapmaktadır. Bu çalışmaları da "sendikaların küreselleşmeye cevabı" başlıklı bir araştırmada literatüre kazandırmışlardır. Bu araştırmada uluslararası sosyal diyalogun, çerçeve anlaşmalarla sağlanması, sendikalar ile ilgili gündemin geliştirilmesi, ittifak ve network sağlanması kapsamında yönetişim ve hesap verilebilirlik için çeşitli ülke, bölge ve küresel düzeyde bazı örnekler sunmaktadır. (Schmidt V. , 2007). ILO sendikaların küreselleşmeye cevabı başl1klı araştırasının beşinci bölümünü oluşturan Tudway'in "işçilerin çıkarlarının korunması ve geliştirilmesi amacıyla şirket yönetişiminin reform edilmesi” makalesini sendikaların küreselleşmeye olan cevaplarından biri olarak göstermektedir. Tudway çalışmasında; şirket sahibi ve yöneticisi olan işverenlerin işçilerin üzerinde ekonomik ve sosyal sorumluluk açısından bazı yaptırımları olduğunu ve bu yaptırımların çoğu zaman yıkıcı sonuçlar verebildiğini belirtmektedir. Bu yüzden sendikaların şirketlerin yönetim yapılarının şeffaflaştırılması ve katılımcı olmasına katkı sağlaması gerektiğini ifade etmektedir (Tudway, 2007). Aynı çalışmada Schmidt küresel yönetişim çerçevesinin sendikaların emek lehine ittifaklar kurabileceği şekilde yeniden düzenlenmesi gerektiğini belirtmektedir (Schmidt E. , 2007).

Hellman, uluslararası çalışma standartlarının ortaya konulup ülkelerde uygulanabilmesi için uluslararası çerçeve antlaşmalarının önemine vurgu yapmaktadır. Hellaman'a göre bu antlaşmalar gelecek dönemlerde endüstri ilişkilerinin şekillenmesinde önemli bir yere sahiptir (Hellman, 2007). ILO'nun bu çalışmasında Türkiye'deki emek platformunu (Erdoğdu, 2007, s. 153-174). Kolombiya'daki sendikaların ittifak oluşturma gayretlerini (Perez \& Mc Donough, 2007), kadın işgücünün örgütlenmesini (Fonow \& Franzway, 2007), 
İngiltere'de ve Polonya'da sendikaların göçmen işçiler için uyguladıkları örgütlenme stratejilerini (Hardy \& Clark, 2007), iletişim teknolojisinde çalışanların sendikacılık eğilimlerini (Comelo, 2007), çok uluslu şirketlerin Bulgaristan'daki faaliyetlerini (Daskalova \& Tomew, 2007), aynı şekilde çok uluslu şirketlerin Brezilya'daki faaliyetlerini (Scherer, 2007), araştırılmış ve sendikaların küreselleşmeye karşı cevabı olarak somutlaştırmıştır.

Buraya kadar anlatılan kısımdan varılabilecek sonuç ise küreselleşmeye karşı cevap verilebilmesi için uluslararası ve bölgesel sendikal hareketi oluşturan kurumların bu konuya yaklaşımı önem taşımaktadır. Bu bağlamda ilk olarak ICFTU, WCL birleşerek küresel bir örgüt olan ITUC'u oluşturmuşlardır. Bu oluşumun hemen öncesinde ise yerel ve bölgesel sendikaların küreselleşmeye karş1 daha etkin olarak mücadele etmesine ve daha güçlü politikalar geliştirmesine katkı sağlayacak olan sendikalar için küreselleşme rehberleri hazırlanmıştır. İki bölümden oluşan bu rehberin ilk bölümünde küreselleşmenin sendikalar üzerindeki etkilerini ve uluslararası sendikal hareketi tanımlamaktadır. Uluslararası sendikal hareketin ana hedefleri olarak ekonomik ve sosyal adalet için uluslararası bir çerçeve oluşturmanın yanı sıra sendikal hak ve çalışma standartlarını savunmak ve teşvik etmek, çok uluslu şirketlerin sendikaların geleneksel rolüne ilişkin zorlukları ve sendikaların ÇUŞ'larla nasıl birlikte çalışabileceğini anlatmaktadır. İkinci bölümünde ise tüm sendikal örgütler için küreselleşmenin ortaya çıkardığı zorlukları yerel, ulusal ve bölgesel düzeyde incelemiş ve yanıtlar aramıştır. Uygun uluslararası sendikal örgütlere katılmanın önemine vurgu yapmıştır (ICFTU, 2001). Bunun yanında ICFTU 1996 yılından bu yana genel kurullarında ve gerçekleştirdiği kongrelerde genel olarak küreselleşmeye karşı cevap temasını işlemiş ve küresel eylemlerin gerekliliğine, örgütlenmeye, sendikal hakların geliştirilip yeniden şekillendirilmesine ve küresel sosyal adalete vurgu yapmıştır. Bu doğrultuda uluslararası sendikal hareketin küreselleşmenin itici gücü olarak kabul edilen Dünya bankası, IMF, DTÖ gibi uluslararası kurumların küreselleşmeyi yaymak ve sendikaların etkinliğini azaltmak adına geliştirdiği politikalarla mücadele etmek amacıyla çeşitli politikalar geliştirmeye çalışmaktadır. IMF ve DB'nın ürettiği politikalara alternatif politikalar geliştirerek insana yakışır iş (decent work) ve istihdam politikalarını geliştirmeyi hedeflemiştir (ICFTU, 2018).

ICFTU ve WCL'nin birleşmesinden sonra oluşan güçlü bir küresel birlik olan ITUC da küreselleşmeye karşı mücadeleyi felsefe edinmiş zira kuruluş 
gerekçesini de küreselleşme sorunlarını ortadan kaldırmak olarak belirlemiştir. Yine ITUC'a bağlı olan ve bir bölgesel örgüt olan ETUC'un da küreselleşmenin ortaya çıkardığı sorunlara karşı ciddi bir mücadelesi vardır. Londra'da 2008 yılında yapılan toplantıda ETUC sendikaların önündeki temel sorun alanlarının göçmen işçiler ve çalışma şartları, Küreselleşme ve Avrupa, ÇUŞ politikaları, kayıt dışı ekonomi, sosyal diyalog, eşitsizlikler, AB Temel Haklar Sözleşmesi, sendikal üyelik gibi sorunların olduğunu ifade etmiştir (ETUC, 2018).

Bu noktada küresel bir üst örgüt olan ITUC ve Bölgesel bir örgüt olan aynı zamanda çalışmanın temel öznesi olan ETUC'un küreselleşme karşısında vermiş olduğu tepkilerin bir örneği olarak 2008 küresel krizindeki tavırlarını incelemenin yerinde olacaktır.

\section{Küresel Kriz'e Karşı ITUC'un Tepkisi}

Küreselleşmenin dünya ekonomilerini birbirine bağlamasından dolayı etkisi oldukça büyük olan 2008 küresel krizi 2009 yılında itibaren sorunlarını iyice hissettirmiştir. Sendikalar krizin getirdiği bu sorunlara karşı yeni politikalar üretmek ve krize aynı zamanda küreselleşmeye karşı olan tepkilerini belli etmek için deklarasyonlar, toplantılar ve çeşitli eylemler düzenlemişlerdir. ITUC öncelikle diğer küresel sendikal organizasyonlarla da işbirliği yapmanın gerekliliğini vurgulamış ve bu organizasyonlarla birlikte uluslararası siyasi karar alma süreçlerinde etkin bir şekilde yer almak istemektedir. Bunun için ILO'nun içinde bir kuruluş olan "sendika dayanışma komitesi (TUAC)"ne üye sendikalar ile işbirliği yaparak gerçekleştirmeye çabalamaktadır. ITUC'a göre 2008 küresel krizi gibi büyük çaptaki krizler günümüz dünyasında önceden tahmin edilemeyecek ve sonuçları bakımından sosyal ve politik istikrarsızlığa neden olacaktır. Nitekim son dönemde sosyal uyum, yapısal uyum gibi programlar pek çok ülkede çalışma hayatında yaşanan adaletsizlikten, dolayı tehdit altındadır (Erdut, 2002). Zira 2008 krizinde hiçbir sorumluluğu bulunmayan kişiler evlerini, işlerini, emeklilik haklarını kaybetmemişler ve bir de üzerine küresel yarayı sarmak için mali destek sağlamaları gerektiği küreselleşmenin ekonomik kurumları içinde tartışılmaktadır. ITUC'a göre bu süreçte sendikalar sosyal diyalog mekanizmalarında çok daha etkin olmalı ve eğer mümkünse ekonomik kararların alındığı toplantılara da katılmayı kritik görmektedir (ETUC, 2018). Bu konuda ITUC G-20 zirvelerini önemli görmekte ve zirvelerden önce deklarasyonlar yayınlamaktadır. Bunun ilk örneğini 2009 Washington 
Deklarasyonu olarak gösterilebilir. Zira deklarasyonda ITUC dört temel noktaya vurgu yapmıştır. Bunlardan ilki reel ekonomiye yönelik olarak iyi koordine edilmiş kapsayıcı bir iyileştirme planı, ikincisi küresel ekonomik ve mali piyasaların yeniden düzenlenmesi, üçüncüsü yeni bir yönetişim sistemi oluşturularak uluslararası ekonomik sistemin düzenlenmesi ve sonuncusu dağıtıcı adalet krizi şeklinde önerilerini bu deklarasyonla sunmaktadır (ITUC, 2018). 2009 yılında yine G-20 zirvesinin hemen öncesinde Londra deklarasyonu yayınlanmıştır. Buna göre devletlerin istihdam yaratacak kamu yatırımlarına yönelmesi gerektiği, aktif istihdam politikalarına ağırlık verilmesinin önemi, sürdürülebilir bir büyüme politikasının gerekliliği, sosyal yardımlar vasıtasıyla bu küresel krizin etkilerini zaten zayıf olan kesimler üzerindeki yükü azaltmak, krizde batan bankaların kamulaştırılması, ücretlerin düşmesini engelleme ve gelir dağılımındaki adaletsizliğin zayıflatılmasına ilişkin ILO, OECD, IMF, DTÖ, DB gibi uluslararası ekonomik kurumlara yönelik sendikal beklenti ve öneriler deklarasyonunun gündemini oluşturmuştur. Nitekim G-20'nin Londra zirvesinden sonra yaptığ 1 açıklamada zirveden beklentilerine yönelik olarak başarılı sonuçların çıktığını, Washington zirvesine göre oldukça ciddi ilerleme kaydedildiğini ifade etmiştir (ITUC, 2008).

\section{Küresel Kriz'e Karşı ETUC'un Tepkisi}

ITUC'un küresel krize karşı tepkisi yukarıda da ifade edildiği gibi daha çok deklarasyon şeklinde gelişirken, ETUC duruma tepkisini genellikle eylemlerle yapmaktadır. ETUC küresel krizin ilk olarak patlak verdiği 2008 yılında Strazburg, 2009 y1lında Londra, Madrid, Brüksel, Berlin ve Prag'ta Avrupa genelinde ses getiren eylemler yapmışlardır. Bu noktada ETUC'un bölgesel bir örgüt olmasına rağmen ITUC'a göre daha sert tepki verdiğini söylemek mümkündür. Örneğin Haziran 2010 tarihinde gerçekleşen ETUC İcra Kurulunda alınan Avrupa risk altında başlıklı kararına göre oldukça eylem ağırlıklı, farklı ve özgün birtakım hususlara yer vermektedir. Yeni bir vergi kaynağı önerisi olarak finansal işlemler vergisi oluşturulması, yeni bir model olarak kapitalizmden dönüş sürecinin başlatılması, 2008 yılında ve bunda sonra yaşanabilecek krizleri 1930'lu y1llardaki krizlere benzeterek kriz ve fazla üretim bağlantısının kurulması ve bu bağlantıdan kaynaklı olarak Avrupa'da aşırı sağın yükselmesi arasında bağlantı olduğu iddia edilmektedir. Bu tezlerini ise Avrupa'da ve Dünyada yaşanan sağ eğilimlerin yükselişi olarak göstermekte bunu da Fransa, Macaristan, Hollanda, Avustruya, Belçika gibi Amerika' da da aşırı sağın temsilcisi Donald 
Trump'ın başkan seçilmesi örnek gösterilmektedir ETUC'un temel hedefi aşırılıkların önüne geçmek ve temsil ettiği kitle için en iyi faydayı sağlamaya çalışmaktır. Bunun yanında ETUC'un üyesi olan sendikaları da gerek yukarıda örnek olarak ifade edilen ekonomik kriz dönemlerinde gerekse küresel mücadelede etkili ve başarılı olabilmeleri için "militan" sendikacılık yapmaya yöneltmektedir. Yukarıda kısaca isimleri zikredilen eylemleri Avrupa geneline yaymaya ve bir koordinasyon içinde organize etmeye çalışmaktadır (Çelikkaleli, 2012, s. 109-115).

ETUC küresel mücadelede bu kadar sert ve tam anlamıyla örgütlenme stratejisini benimsemişken neden paydaş bir role bürünmeye başladı? İşte çalışmanın özünü oluşturan bu sorunun yanıtı ilerleyen bölümlerde açıklığa kavuşturulmaya çalışılacaktır.

\section{Avrupa Birliği Sürecinde Sendikal Gelişim}

Geçmişten günümüze kadar bakıldığında sendikalar, işletme ve ulusal düzeyde işçi ve işverenlerin önemli kazanımlar elde etmelerini sağlamıştır (Freeman \& Medoff, 1984). Sendika denildiğinde ilk olarak akla emeğin insani yönünü vurgulayan kurumlar gelse de sendikalar aynı zamanda iktidarın etkilemesi bakımından bir kontrol mekanizması ve demokratik değerler ile kültürel değerlerin korunmasına yönelik önemli örgütlerdir (D'Art \& Turner, 2007). Nitekim Avrupa'da sendikalar refah devletinin gelişiminde, sosyal politika ve sosyal modelin şekillenmesindeki en önemli mekanizmalardan birisidir (Radcliff, 2005, s. 514-517) (Hyman R. , 2005, s. 12-15). Hiç şüphesiz sendikalar üyelerinin hak ve çıkarlarını korumak ve geliştirmek için en önemli örgütlerdir ve özellikle dönüşüm söyleminin ortaya attı̆g iş̧̧i temsilciliğinin alternatif bir modeli olarak görülen İKY sendikaların ve sendikal temsilin yerini tutamaz (D'Art \& Turner, 2003, s. 174-176) (Kılıç, 2014, s. 111-136). Sendikalar tüm dünyada olduğu gibi özellikle Avrupa' da II. Dünya Savaşı'ndan sonra muazzam bir gelişme ve buna bağlı olarak üyelik sayısında ciddi bir artış yaşamıştır. Bu gelişme pek çok Avrupa ülkesinde 1980'li yıllara kadar sürekli bir büyüme ile devam etmiştir (Ebbinghaus \& Jelle Visser, 2000, s. 104). Fakat 1980'li yıllarla birlikte ekonomik, siyasi ve sosyal yapılarda yaşanan değişim etkisini sendikalar üzerinde de göstermiştir. 1980-2003 yılları arasında İsveç, Danimarka ve Finlandiya gibi Kuzey Avrupa ülkeleri hariç çoğu Avrupa ülkesinde sendikal yoğunlukta bir düşüş görülmüştür (Visser, 2006, s. 44). Günümüzde de 
sendikaların yaşadığı bu üye kaybı sürmektedir. Sendika üyeliğindeki ve sendikal yoğunluk düzeylerindeki düşüş Avrupa'da ve dünyanın pek çok ülkesinde sendikalara karşı toplumsal olarak olumsuz bir tavrın oluşmasına yol açmıştır. $\mathrm{Bu}$ durumun arkasında yer alan sebep ise birçok ülkede neo-liberal politikaların ve düşüncelerin hakimiyetini artırmış olmasıdır. Zira neo-liberal politikalar düşük sosyal harcamalar ve vergilendirme, finansal ve işgücü piyasalarının serbestleştirilmesini ve devletin özelleştirmeler ile küçültülmesini ön gören piyasa mekanizmasının önceliğini savunmaktadır. Dolayısı ile sendikalar piyasa mekanizmasını zorlayıcı bir güç olarak görülmekte ve sendikaların işlevsiz kalması ya da bu stratejilere uyumlu politikalar izlemesi istenmektedir (Pollin, 2003) (Harvey, 2005) (Turner \& D'Art, 2012, s. 35). Fakat tarihsel süreçte izlendiği üzere uygulanan iktidar politikalar her dönem emeğin ve dolayısı ile emeğin örgütlü bulunduğu sendikaların tepkileri karşısında zorlanmıştır (Ferner \& Hyman, 1992). Bu noktada konumuzun odağına geri dönecek olursak sendikaların özellikle Avrupa sosyal diyaloğu içerisindeki yeri ve önemi, her ne kadar neo-liberal politikalar etkili olsa da, sendikalar sosyal diyalog içerisindeki müzakerelerde yapılan teklifleri kabul etmeyerek veya teklifleri üyelerinin çıkarları doğrultusunda şekillendirerek Avrupa sosyal standartlarının oluşumunda katkıda bulunmaktadır. Dolayısı ile sendikalar her ne kadar sistem içerisinde istenmese de sosyal diyalog mekanizmasındaki yeri bakımından mevzuatı etkileme firsatına yasal olarak sahiptir.

\section{Avrupa Birliği Sosyal Diyaloğu Çerçevesinde Sendikaların Rolü}

Avrupa Sendikalar Konfederasyonu (ETUC), bir kamu katılımı olan Avrupa İşletmeler ve Genel Ekonomik Çıkar İşletmeleri (CEEP), Avrupa özel sektör işverenlerinin temsil kuruluşu olan BUSINESSEUROPE (eski adı ile UNICE), Avrupa Sanatkârlar, Küçük ve Orta Ölçekli İşletmeler Birliği (UEAPME) ile birlikte Avrupa Birliği yapısındaki en önemli sosyal taraflardan birisidir.

Bu başlık altında ilk olarak, Avrupa Birliği Sosyal Diyaloğu çerçevesinde karar alma ve mevzuat oluşturma bakımından sosyal ortakların ve sendikaların rolü tartışılacak sonrasında işçileri temsil eden sosyal taraf olarak ETUC'un rolü incelenecektir.

Avrupa Birliğinin kendine has yapısından ötürü sendikalar ile olan ilişkileri, devletlerin ve sendikaların arasındaki ilişkiden yapısal olarak daha farklıdır. Avrupa Birliği genel olarak “sosyal boyut”u ile Avrupa’nın daha geniş bir 
bütünleşme sürecini ve Avrupa sosyal modelinin temel prensiplerini uluslararası düzeye çıkarmayı hedeflemektedir. Başka bir ifade ile Avrupa Birliğii, Avrupa’nın entegrasyon sürecini sosyal boyut ile tamamlamayı ve sürdürmeyi amaçlamaktadır (Waddington, 2005, s. 518-519). Bu bakımdan sendikalar da Avrupa Birliği sosyal modeli içinde ve Avrupa Birliğinin sosyal politikalarının belirlenmesinde önemli bir role sahiptir (Hyman R. , 2005, s. 11)

Yukarıdaki ifadelerden de anlaşılabileceği üzere Avrupa Birliğinde sendikaların rolünü daha anlaşılır olabilmesi için bu başlık altında Avrupa Birliği Sosyal Diyaloğuna kısaca değinilecek ve arkasından Avrupa Birliği'nin sendikalar ile olan ilişkisi açıklanmaya çalışılacaktır.

Avrupa sosyal diyaloğu Avrupa Birliği düzeyinde gün geçtikçe önem kazanan ve Avrupa'nın genel özelliklerini taşıyan geniş boyutlu bit kavramı ifade etmektedir. Kavram temel de işçi, işveren ve bunların hükümetlerle arasında oluşan kurumsal ilişkileri ifade ediyor olsa da bu ilişkiler sosyal ortaklık, üçlü ilişkiler, politikaların birbirleri ile uyumlu hale getirilmesi, uzlaşmacı demokrasi ve sosyal korporatizm gibi pek çok kavramla ilişkilidir (Koray \& Çelik, 2007, s. 7-9). Başka bir ifade ile Avrupa birliği düzeyinde müzakere, danışma ve karar verme aşamalarını içeren, sosyal tarafların kendi aralarında ve hükümetle yaptıkları fikir alışverişi neticesinde çıkarların karşılıklı görüşülmesi ve uzlaşma hedefinde olan bir mekanizmadır. Avrupa Birliği sosyal diyalog mekanizması üye ülkelerin kendi ekonomik ve sosyal politikalarından kaynaklanan farkların barışçıl çözüm yolu ile birbirlerine uyumlu hale getirilmeye çalışılmasıdır (Parlak, 2002).

Avrupa sosyal tarafları arasındaki diyalog sektörel ve sektörler arası düzeyde ortaya çıkmaktadır. Sektörler arası diyalogların katılımcıları da ETUC, BUSINESSEUROPE, UEAPME ve CEEP'tir. 1960'l y yllarda ekonomik ve sosyal sorunlara ilişkin sosyal taraflar arasındaki görüş alışverişleri daimi komiteler vasıtasıyla yapılmaktaydı (Bu durum Avrupa sosyal diyaloğunun bu y1llarda da mevcut olduğunu göstermektedir). Fakat Jacques Delors'un 1985 'te Avrupa Komisyonu başkanı olması ile birlikte iki taraflı sosyal diyaloğa daha fazla önemin verildiği ve Avrupa sosyal diyaloğunun yeni bir boyut kazandığ1 görülmektedir (ETUC, 2018). 1985'ten günümüze kadar sosyal diyalog mekanizması sosyal taraflara giderek daha geniş yetkiler tanıyan üç aşamadan geçmiştir. 1985-1991 arasındaki ilk dönemde iki taraflı faaliyetler, herhangi bir bağlayıcı güç olmaksızın, kararların, beyanların ve ortak görüşlerin 
benimsendiği dönemdir. 1992-1999 arasındaki ikinci aşama, Maastricht Antlaşmasının imzalanması ile başlayan süreçtir bu süreçte sosyal diyaloğun resmi ve kurumsal bir nitelik kazanması sağlanmıştır. Üçüncü aşama ise Aralık 2001'de Avrupa sosyal ortaklarının Laeken Avrupa Konseyine ortak bir katk1 sunmaları ile başlamıştır. Bu aşama artık sosyal diyalog için daha fazla bağımsızlık ve özerklik ile karakterize edilmiştir (Lapeyre, 2015).

Son olarak 2012 de onaylanan Avrupa Birliğinin İşleyişine İlişkin Antlaşma (TFEU, The Treaty On The Functionıng Of The European Unıon) ile Avrupa sosyal ortaklarının Avrupa Birliği politikasının oluşturulmasında katılımını teşvik etme politikası vurgulanmış ve Komisyon tarafindan sosyal taraflara danışılmasını içeren prosedürler belirlenmiştir. Nitekim Antlaşmanın 154. Maddesi, Komisyonun sosyal politikaya ilişkin tekliflerini sunmadan önce yönetim ve işçilere danışmak zorunda olduğunu ifade etmektedir. Bu ifadeden de anlaş1labileceği üzere, sosyal taraflara Avrupa Birliği düzeyinde karar alma süreçlerine etki edebilme ve yönlendirme firsatı sunulmaktadır (ETUC, 2018). Sosyal diyalog mekanizması Avrupa Komisyonuna göre iki taraflı bir mekanizmadır. Başka bir deyişle görüşme masasına işverenler ve işçiler yer almaktadır. Kamu makamları ise endüstri ilişkilerinden kaynaklanan rolleri gereği masanın iki tarafına da yer alabilmektedir. Kamu kurumları bu görüşmelere dahil olduğunda mekanizma üçlü diyalog ya da üç taraflı sosyal diyalog olarak isimlendirilir (Commission, 2018). Aslında ikili diyalogdan anlaşılması gereken sözleşmeler ve Avrupa sosyal ortakları tarafindan imzalanmış ancak herhangi bir direktifte yer almayan otonom anlaşmalar da dahil olmak üzere yönetim ve işçi tarafının sorunları ikili olarak görüşmeyi talep ettikleri bir seçenektir. İmzalayan taraflar için sözleşmeler ulusal endüstri ilişkileri sistemlerine uyumlu seviyelerde uygulamaları konusunda taraflara bir sözleşme yükümlülügüü yaratır ve dolayısıyla komisyonun yasama girişimi askıya alınır (Comission, 2018). Böylelikle işçilerin ve işverenlerin aktif katılımları çıkarları ile ilgili daha olumlu sonuçlar üretmesi, mevzuatı ve karar alma süreçlerini kendi çıkarları doğrultusunda etkileyebilmeleri açısından oldukça önemlidir. Müzakereler başarılı olduğu takdirde anlaşma sosyal ortakların ulusal endüstri ilişkileri uygulamalarına uygun olarak uygulanmaya başlayabilir. Bu durum gönüllü yol olarak da ifade edilmektedir. Müzakereler sonucundaki anlaşma tüm çalışanları kapsaması için uzlaşma kararını teklif etmek üzere Komisyona sunulur. Bu toplu görüşme esnasında Avrupa Parlamentosunun resmi olarak bir katılımının olmaması sosyal tarafların mevzuatı dikte ettiğin yönünde bazı 
milletvekillerinin eleştirilerini almaktadır. Müzakerelerin başarısız olması durumunda ise Komisyon geleneksel yasama yolunu izleyen bir öneride bulunabilir. Sürecin bu şekilde işlemesi ve başarılı sonuçlar elde edilmesi sosyal diyalog mekanizmasından beklentilerin çok üzerinde bir fayda elde edildiği görülmektedir. İşçi ve işverenler arasında süregelen bu merkezi toplu görüşmeler ve anlaşmalar merkezi hukuk kurallarının bir sonucudur. Fakat küreselleşme ve rekabet ortamında liberal hükümetler buna karşı çıkmakta özellikle endüstri sektöründeki anlaşmaları terk etmekte ve daha çok tek işverenli görüşmeleri tercih etme eğiliminde olduğu görülmektedir (Barnard, 2002, s. 81-82).

\section{Avrupa Birliği Seviyesinde Çalışma Hayatının Birincil Temsilcisi Olarak ETUC}

Avrupa Birliği düzeyinde sendikaların çıkarlarını temsil eden en önemli ve en büyük kuruluş olan ETUC (Avrupa Sendikalar Konfederasyonu) 1973 yılında kurulmuştur. Halihazırda 39 ülkedeki 89 ulusal sendika konfederasyonu ve 10 Avrupa sendika federasyonunun birleşmesinden oluşmaktadır. ETUC geniş bir organizasyon yapısına sahip ve demokratik ilkelere karar alma sürecinde oldukça önem veren bir örgüttür (ETUC, 2018).

ETUC'un temel amacı, istikrarlı bir Avrupa oluşturulması için Avrupa Sosyal Modeli'nin desteklenmesi, çalışanların ve çalışanların ailelerinin insani, sivil, sosyal, istihdam haklarının ve yüksek yaşam kalitesi içinde birlikte barış içinde yaşamasını sağlamaya çalışmaktır (ETUC, 2018). ETUC sürdürülebilir ekonomik büyümenin sağlanabilmesi için, sosyal koruma, tam istihdam, firsat eşitliği, kaliteli iş ve sosyal içerme gibi sürekli gelişen iş ve yaşam koşullarıyla birleştirmenin mümkün olduğunu varsaymaktadır (Itschert \& Bir, 2012, s. 32-34).

Avrupa Birliği sosyal diyaloğunda yer alan diğer aktörlerinkine benzer şekilde ETUC'un üç temel işlevi olduğundan söz edilebilir. Bunlardan ilki yürütülen lobi çalışmaları kapsamında üyelerine bilgi hizmetleri sunmak ve bunun koordinasyonunu sağlamak, ikincisi ortak karar alma süreçlerinde Avrupa Birliği kurumları önünde üyelerinin çıkarlarını güçlü bir şekilde temsil etmek, sonuncusu ise işveren örgütleri ile çalışma hayatına yönelik müzakerelere aktif olarak katılmak ve kendi çıkarları doğrultusunda uzlaşmaya varmaya çalışmaktır (Welz, 2008, s. 137-144). Aynı zamanda ETUC, Avrupa Komisyonu ile sık ve doğrudan temaslar kurarak, Avrupa Sosyal ve Ekonomik Komitesinin bir parçası olması yönüyle, Avrupa Parlamentosu milletvekilleri ile kurmuş olduğu yakın 
temas ve iş birlikleri ile düzenli temsil yoluyla Avrupa Birliği'nin istihdamı, sosyal konuları, makro ekonomi politikalarını ve kural koyma sistemlerini etkilemeye çalışmaktadır. Bu noktada ETUC Avrupalı işveren ve işveren örgütleri ile birlikte Avrupa endüstri ilişkilerini şekillendirme sürecinde bir ortak statüsündedir. Dolayısı ile ETUC'u Avrupa Birliği düzeyinde en önemli emek temsilcisi olarak göstermek mümkündür.

\section{ETUC Yapısı ve İç Bölümleri}

ETUC, bahsedildiği üzere bölgesel olarak farklı ideolojileri benimsemiş, farklı stratejileri olan birbirleri ile çok fazla ortak özelliği olmayan sendikalardan oluşan büyük bir üst örgütlenmedir. ETUC'un üyeleri arasında hem ulusal sendika konfederasyonları (Türk-İ̧s, DİSK, Hak-İş) yer alırken hem de Avrupa sendika federasyonları yer almaktadır. Ayrıca Avrupa İş Konseyleri (EWC), Avrupa Meslekli ve İdari Personel Konseyi (EUROCADRES) ve Avrupa Emekli ve Yaşlılar Federasyonu (EFREP/FERPA) da ETUC'un üyeleri arasındadır. ETUC'un kurulduğu günden bu yana kadın komitesi ve gençlik grubu bulunmaktadır. Üyelerinden de anlaşılabileceği gibi ETUC Avrupalı işçilerin tek ve güçlü sesi olabilmek için karışık ve kapsayıcı bir yapıya sahiptir (ETUC, 2018).

ETUC'un örgütsel yapısı ve karar verme süreci demokratik niteliktedir. En önemli organı, konfederasyonun politikalarına karar veren Kongre'dir. Kongre dört yılda bir toplanır ve toplantılara ulusal konfederasyonlardan ve Avrupa sendika federasyonlarından delegeler katılır. Tüm organların üyelerini seçer.

İcra Komitesi, ETUC üyelerinin üyelikleri ile orantılı olarak gönderdikleri temsilcilerinden oluşur. Yılda 4 kez buluşur ortak durumları kabul edebilir ve taleplerini destekleyecek eylemlere geçmek için karar verebilir. Kararlar, oyların üçte ikisinin yeterli çoğunluğu ile alınır. Ayrıca İcra Komitesi, Avrupa işveren örgütleriyle müzakere eden delegasyonların görev ve yetkilerine karar verme yetkisine de sahiptir. Sekretarya, ETUC'un günlük faaliyetlerini yönetir. Sendikanın gerçekleştireceği Avrupa genelindeki sendikal eylem planlarını hazırlar ve önerir. Aynı zamanda ETUC'un iç işlerinden sorumlu olan organıdır.

Daimi Komiteler, faaliyet grupları ve bölgeler arası sendikalar, istihdam ilişkileri, sosyal politikalar, ekonominin demokratikleştirilmesi, çevre, sanayi politikaları, ve eğitim gibi konular da dahil olmak üzere çeşitli ETUC politikaları ile ilgilenmektedir. ETUC Kadın Komitesi, toplumsal cinsiyet eşitliği üzerine 
odaklanılması ve kadınların çalışma hayatındaki sorunları için, ETUC Gençlik Komitesi genç işçilerin karşılaştığ özel sorunları dikkate almak için oluşturulmuştur. FERPA (Avrupa Emekli ve Yaşl1lar Federasyonu) sosyal güvenlik, özellikle emeklilik ve sağlık hizmetlerinin iyileştirilmesine, sosyal dışlanmaya ve yoksulluğa karşı mücadeleye odaklanmaktadır.

Avrupa Sendikalar Enstitüsü (ETUI), uzmanlıklarını işçilerin çıkarlarının hizmetine Avrupa düzeyinde sunan bağımsız araştırma ve eğitim merkezidir.

ETUC diğer konfederasyonlara benzer şekilde, çok fazla üye ve üyelerin arasındaki çeşitli çıkar farklılıkları iç bölünmelere ve muhalefetlere yol açar. Hiç şüphesiz ETUC içindeki en hareketli tartışmalar ideolojiler ve politik programlarla ilgilidir. ETUC içindeki sendikaların üye sayısı ve büyüklükleri de birbirilerinden farklıdır. Örneğin Alman DGB veya İngiliz TUC 6 milyon işçiyi temsil ederken San Marino CDLS yaklaşın bin kişiyi temsil etmektedir zira bu durum temsilci sayıları ile dengelenmeye çalışılmıştır. ETUC içindeki üyelerin ülkelerindeki sendikalaşma oranlarının birbirinden farklı olması, ülkedeki endüstri ilişkilerinin düzeyi, coğrafi konumu, diğer sendikalar ile olan iş birlikleri gibi çeşitli özelliklerinden dolayı bazı bölünmeler yaşanabilmektedir (Abbott, 1997, s. 467). ETUC'un karar alma mekanizması bahsedilen iç bölünmeler, federasyon, konfederasyonlardan oluşan iki sütunlu örgütsel yap1, organizasyon şemasından ötürü karmaşık bir hal almakta. Bu yüzden kararlar genellikle en küçük ortak paydaya göre alınmaktadır. Dolayısı ile alınan bu kararlar için oldukça genel ve üye sendikaları çokça tatmin eden kararlar olmadığı söylenebilir (Kirches, 2007, s. 11).

ETUC içinde yaşanan görüş farklılıkları ve çatışmalar tarihsel olarak da değişebilmektedir. İlk dönemlerde ideolojik olarak farklılaşmalar ortaya çıkarken, günümüze yaklaşıldığında sendikaların yeniden canlanma stratejileri bakımından mücadeleci mi yoksa paydaş mı olacakları bakımından farklılıklar görülebilmektedir. Örneğin ETUC'un ilk kurulduğu yıllarda Avrupa'da hem uluslararası hem de yerel düzeyde sendikalar kendi aralarında ideolojik olarak "Hristiyan demokratik, sosyal demokrat ve komünist profili olan sendikalar mevcuttu ve bu da işçilerin çıkar temsilinde farklılıkların ortaya çıkmasına neden oluyordu. Dolayısı ile ETUC'un içinde de farklı düşünceler olmasında etkiliydi (Rowe, 2011, s. 33). ETUC ilk yıllarında yerel sendikalar ve federasyonları için diğer sendikalarla koordinasyon ve yabancı sendikalarla işbirliği oluşturmada destek sağlamaya yönelik hizmet etmiştir. Böyle bir sınırlı 
fonksiyonuna rağmen ETUC bu yıllarda birçok zorlukla karşılaşmıştır. Sorunlar iç bölünmeleri ve üyeler arasındaki farklılıklar, üye örgütlerin kaynaklarını kullanamaması, üyelere aşırı bağımlılık ve ETUC merkezine üyelerin yetki vermek istememesi ile ilgili olmuştur. Bu zorlukların yanında, ETUC'un kurulması ve faaliyetlerinin geliştirilmesi, üye sendikaların Avrupalılaşması sürecine, Avrupa'yı bütünleştirmeye ve Avrupa sosyal politikalarını birlikte şekillendirmeye yönelik firsatları bir araya getirmeye katkıda bulunmuştur (Greenwood, 2011, s. 110).

\section{Stratejik Değişim: Örgütlenme Stratejisinden Paydaşılı Stratejisine}

Schmitter ve Streek iş organizasyonlarının yapısını inceledikleri çalışmalarında organizasyonların üyeliğe ilişkin iki tür felsefenin olduğunu tespit etmişlerdir. Bunlardan ilki örgütlenme stratejisi ile benzer özellikler gösteren üyelik mantığıdır. Üyelik mantığının amacı, üyelerin ihtiyaçlarının ve beklentilerinin karşılanması amacını içeren örgütlenme mantığı, ikincisi ise üyelerin sayısal çokluğuna ve gücüne istinaden siyasal kurumları ve süreçleri etkilemeyi amaçladıkları paydaşlık stratejisine benzer özellikler gösteren etki mantığıdır. Sadece iş organizasyonları ile değil tüm örgüt yapıları işleyişleri için düşünülebilecek bu iki mantık arasında üstü kapalı da olsa bir çatışma yer almaktadır (Schmitter \& Wolfgang, 1999, s. 20). Schmitter ve Streeck’e göre tüm ilgi gruplarının işleyişinde içsel olan bu mantıklar arasında bir çatışma vardır, ancak sendika ve sendikalardan oluşan üst kuruluş olan konfederasyon yapılarında bu çatışma daha belirgindir. "Üyelik mantığı”, örgütü, üyelere özgü ve üyelerin özel beklentilerini yansıtacak bir yapı oluşturmaya zorlar. Etki mantığında ise siyasi etki daha ön planda olduğu için daha geniş ve kapsayıcı örgüt yapısı oluşturulmasını gerekli kılar. Etki mantığı sendikalar için oldukça ince bir çizgide yer almaktadır. Zira eğer bir sendika toplu pazarlık sürecinde karşı tarafa gereğinden çok taviz verirse üyelerini kaybetme ihtimali ile karşı karşıya kalabilir. Diğer taraftan üyeleri tarafından karar alıcı mekanizmalara kendini kabul ettiremeyeceğini ya da hükümetler veya işverenler tarafından sendikaların üyelerini disipline edemeyeceği anlaşılırsa sendikalara güven kaybı artar ve hali hazırda müzakere edilmiş düzenlemelere duyulan inancın azalması riski ile karşı karşıya kalır (Schmitter \& Wolfgang, 1999).

Kısaca bahsedilen süreç diğer örgütlerde olduğu gibi ETUC içinde kritik bir öneme sahiptir. Nitekim ETUC'un ilk kurulduğu dönemlerde üyelerin çıkarlarına 
yönelik hizmet sunduğu ve küreselleşmenin etkisinin iyice kendini gösterdiği dönemde üyelik mantığından uzaklaşarak etki mantığına yöneldiğini söylemek mümkündür. Nitekim küresel karşı mücadele için ETUC'un aldığı bu risk kabul edilebilir görünmektedir. Bu başlı̆̆g izleyen iki başlık altında ETUC'da yaşanan felsefe değişimini ETUC'un tarihsel süreçteki politikaları izlenerek değerlendirilecektir.

\section{Örgütlenme Stratejisinin Hakim Olduğu Dönemin Değerlendirilmesi: Paydaşlık Stratejisi Gelişimi}

ETUC'un kurulduğu yıllarda daha öncede ifade edildiği gibi sendikal hareket bir bütünlük göstermemekteydi. Zira Avrupa'da birbiri ile rekabet halinde olan Hristiyanlığın toplumsal ilkeleri temelli Dünya İşçi Konfederasyonu (WCL), komünist ideoloji temelli Dünya Sendikalar Federasyonu (WFTU) ve sosyalist düşünce temelli Uluslararası Serbest Sendikalar Konfederasyonu (ICFTU) olmak üzere üç uluslararası konfederasyonun mevcuttur (Kirches, 2007, s. 3). Sendikaların ideolojik olarak bölünmesi, Soğuk Savaş sırasında Doğu ve Batı arasındaki ideolojik farklılıktan kaynaklanmaktaydı. Ancak gerek soğuk savaşın son dönemi gerek küreselleşmenin etkisinin artması hem uluslararası sendikalar hem de ulusal sendikalar tarafından, işverenlerin iş örgütlerini birleştirmesi (UNICE ve UEAPME'nin kurulması) ve Avrupa Topluluklarının oluşturulmasına aktif katılımları karşısında, sendikaların ortak Avrupa'yı örgütlemek için işbirliği başlatması gerektiği fark edildi (Ciampani \& Tilly, 2017, s. 13-17). ETUC için başlangıçta ciddi bir fikir ayrılığı yaşadı çünkü ulusal sendikaların temsilcileri yeni oluşan konfederasyonun işleyişi, politik ve coğrafi kapsamı üzerinde anlaşmaya varamamışlardı. En önemli tartışmalar ise siyasi program üzerinden yapılmaktaydı. Nitekim Alman DGB hareketlerini kısıtlayıcı eylemlerin asgari düzeyde olmasını talep ediyor, İngiliz TUC ise geniş yetkinliklere ve karar verme rolüne sahip bir örgüt kurulması projesini savunuyordu (Kirches, 2007, s. 5). DGB'nin desteklediği asgari düzeydeki yaklaşım Brüksel'de sınırlı ve etkin lobi faaliyetleri yürütmenin yanı sıra sadece batı ülkelerinden üyelerin dahil olması görüşünü savunuyordu. Oysa güçlü bir açık örgüt kurma isteğini savunan yaklaşım ETUC'un geniş yetkilere sahip olması gerektiğini varsayıyordu. Sonunda, coğrafi ve politik açıklığı teşvik eden geniş yetkinliklere sahip olan yaklaşım benimsenmiştir. Dolayısı ile, ETUC'un başlangıç aşamasında üyelik mantı̆̆ ile örtüşen, üst düzey özellikleri bulunan, geniş yelpazede ilgi alanlarını temsil eden ve batılı 
ülkeler dışında diğer ülkelerden de üyeliğe sahip yeni bir konfederasyon türü olarak kurulmuştur (Kirches, 2007, s. 4).

80'li yıllarda ETUC kurumsallaşma süreci yaşamıştır. Ancak iç rekabet ve çatışmalardan kaynaklanan zorluklar bu dönemde de devam etmektedir. Çok çeşitli üyeler ve çıkarları, iç mücadeleleri ve ortak konumu belirleyememeye yol açmıştır. Avrupa sendikal hareketinin pek çok analisti başlangıçtan itibaren ETUC'un olağanüstü büyük organizasyonel ve politik kaynaklara sahip olmasına rağmen, Avrupa politikalarını şekillendirme sürecinde etkisinin kaynaklarına orantısız derecede küçük olduğunu vurgulamaktadır (Bernaciak, GumbrellMcCormick, \& Hyman, 2014) (Welz, 2008) (Greenwood, 2011). ETUC bir sosyal partner statüsüne sahip, Brüksel'de temsilci şubesini kurmuş, işverenlerle müzakerelere katılmış olsa da, işveren örgütlerinin nüfuzuna ve gücüne karşı koyamamıştır. Dahası bu durumda ETUC'a üye sendikalar bile ETUC'u sadece bilgi alışverişi ve yerel örgütlerin eylemlerinin koordinasyonu için bir forum olarak görmekteydi (Welz, 2008, s. 140-142).

90'lı yılların başlarında, tek tip bir Avrupa pazarının oluşturulması, Ekonomik ve Parasal Birlik programının ilan edilmesiyle birlikte, ETUC'un faaliyetlerinde de önemli değişiklikler meydana gelmiştir.

İnsanların, malların, sermayenin ve hizmetlerin serbest dolaşımının, iç idari teknik ve mali sınırların kaldırılması kısaca Avrupa Birliği’nin oluşması, Avrupa'daki sendikalar için yeni sorunlar ortaya çıkardı. Böylece sendikalar $\mathrm{AB}$ düzeyinde etkin çıkar temsilciliği yürütme gereğinin önemini algılamaya başladı. Üye Devletler, yetkilerini AB kurumlarına ekonomik ve sosyal politikalar kapsamında aktarmışlardır, bu nedenle eğer yerel sendikal federasyonlar bu politikaların şekillenmesinde yer almak istiyorsa, bu kurumların tecrübelerini hedeflemek ve kendilerini o yönde geliştirmek zorunda bırakılmıştır. Dolayısı ile ETUC'un ana AB kurumlarıyla ilişkileri genişletmesini ve güçlendirmesi üyeleri tarafından bekleniyordu. Çıkar temsilinin harekete geçirilmesi için önemli bir faktör de ETUC'un Avrupa emek kesiminin birincil temsilcisi olarak korunması ve güçlendirilmesi amacını taşıyan Avrupa Komisyonu tarafindan da kabul edilen Avrupa-sendikacılığın teşvik edilmesi stratejisidir (Turner L. , 1996, s. 329-332) Komisyonun bu stratejisinin altında yatan neden işveren tarafının sosyal diyalogdaki orantısız gücünün dengelenmeye çalışmasıdır. Başka bir ifade ile sosyal tarafların Avrupa Sosyal Diyaloğundaki pozisyonlarını dengeleme amacidır (Kirches, 2007, s. 6). 
Paydaşlık Stratejisine Doğru Yönelim; ETUC'un gelişiminde bir sonraki aşama Ekonomik ve Parasal Birliğin kurulması, Avrupa sosyal politikasının geliştirilmesi, Maastricht Antlaşması'na Sosyal Protokolün eklenmesi, Orta ve Doğu Avrupa'daki Avrupa Sosyal Diyaloğu ve siyasi sistem dönüşümünün kurulmasıyla başladı. Bu yeni gelişmeler beraberinde yeni zorluklar getirdi. ETUC yetkilerini, etkinliğini, esnekliğini ve gücünü artırma amaçlı reformları uygulamaya zorlandı. Siyasi program ve karar alma süreçlerinde değişiklikler yapıldı, ETUC'un liderliği güçlendirildi, Brüksel'deki sekretarya personeline ek yetki verildi ve Orta ve Doğu Avrupa sendikalarının üyeliğe katılması sağlandı. 1995'te ETUC'un pazarlık kapasitesini daha etkili hale getirmek için yeni yetkilendirme prosedürünü tanıtmak amacıyla Anayasa değişikliğine gidilmiştir. Bu reform, Keller ve Sörries tarafından, ulusal sendikal politikaların Avrupalılaşması yönünde önemli bir itici güç olarak görülmektedir (Keller \& Sörries, 1999, s. 117).

Bu yeni gelişmeler ETUC'un durumunu, temsil kabiliyetini ve bir dereceye kadar da profilini değiştirdi. Ancak üye federasyonların çoğunluğu hala ETUC'u gerçekten ulus-üstü yapılara dönüştürmeye karşı çıkmaktaydı (Kirches, 2007, s. 6).

Bu değiş̧iklikler, zamanın Avrupa Komisyonu başkanı Jacques Delors'un, Avrupa Sosyal Diyaloğu'nu şekillendirmedeki kararlılığının yanı sıra, ETUC'un nispeten zayıf bir sendikal örgütlenmeden güçlü ve kararlı bir sosyal ortak haline dönüşmesine neden olmuştur (Greenwood, 2011, s. 107). $\mathrm{Bu}$ durum Avrupa düzeyinde endüstri ilişkilerinin kurumsallaşma sürecinin önemli bir aşaması olarak görülebilir. ETUC'un Avrupa Sosyal Diyaloğunda çok geniş işlevleri olmasa da sosyal taraflar içinde gücünün üzerinde hareket etmekte ve adeta Avrupa'da siyasi bir lider rolünü oynamaya çalışmaktadır. Siyasi lider olarak yükselen rolün bir örneği, sosyal meselelere ayrılan genişletilmiş bir kısım da dahil olmak üzere, Avrupa anayasasının yürürlüğe girmesi için kampanyaların yanı sıra, tekdüze pazardaki hizmetlerin sunulması özgürlüğü ile ilgili direktifin yürürlüğe konulmasına yönelik kampanyadır (Mittag, 2017, s. 32-33).

AB politikalarını şekillendirmede rolünün kurumsallaşmasını hızlandırmaya çalışmak ETUC'un Avrupa Komisyonu ve Avrupa Parlamentosu ile işbirliğinin artmasına neden olmakta. Artık faaliyetlerinde AB kurumları ile olan ilişkilerini daha çok kuvvetlendirerek siyasi etki fonksiyonuna doğru yönelmektedir. 
Bununla birlikte, bu yönelim ETUC'a bazı avantajların yanında dezavantaj da getireceği açıktır. Avrupa istihdam ve sosyal işıler ile çatışmasız ilişkilere dair konfederasyonun stratejik kararı Avrupa Komisyonu kararlarına karşı aşırı uzlaşmacı bir yaklaşım göstermekte ve AB kurumlarına bağımlılı̆ga yol açmaktadır (Kirches, 2007).

Hyman'a göre ETUC'un başlangiçtaki felsefesinden daha sonra yöneldiği siyasi felsefe arasında net bir yer seçememiş olması ve AB yönetimi ile olan açık ve uzlaşmacı stratejisi Avrupa Komisyonu tarafindan çıkarları doğrultusunda kullanılmaktadır (Hyman R. , 2005, s. 26-29). Bu sebepten dolayı ETUC bazı üye sendikaları ile sorunlar yaşamaktadır dolayısı ile bu sendikalar maddi destek sağlamaktan çekinmekte ve ETUC'u AB kurumları ile daha yakın ilişkilere sokmaya zorlamaktadır. Resmi olarak ETUC gelirlerinin ana kaynağı üyelik ücretleri olsa da, faaliyetlerinin maliyeti Avrupa Komisyonu sübvansiyonlarından karşılanmaktadır (Martin \& Ross, 2001, s. 53-76). Fakat bu yakın işbirliği ve Avrupa Sosyal Diyaloğuna katılım, Avrupa' daki iş dünyasının en önemli temsilcisi olarak konumunu sağlamlaştırmış ve $\mathrm{AB}$ politikalarında kilit rol oynama etkinliğini arttırmıştır. Ancak bu durum, üyelerden eleştiri almasının önüne geçememiştir (Welz, 2008, s. 143) (Hyman R. , 2005, s. 21)

ETUC, AB yönetiminin planlarına asla açıkça karşı koymadı. Bunun bir örneği, AB'de ekonomik kalkınmayı hızlandıran neo-liberal bir program olan “Avrupa 2020” AB programına karşı konfederasyonun neredeyse hevesli bir duruş sergilemektedir. Program, Avrupa ekonomisinin rekabetçiliğini radikal bir şekilde artıran çözümlerin yanı sıra kamu harcamalarını sınırlandırma planları içermesine rağmen, ETUC onları Avrupa sosyal modeli için tehlikeli olarak görmemiştir (Hyman R., 2005, s. 23). ETUC’un Paydaşlık Stratejisi; Avrupa Birliği’ndeki en büyük genişleme dönemi olan 2004-2007 arası dönem ETUC için oldukça önemlidir. Bu genişleme dönemi sadece Avrupa Birliğine üye ülkelerin ve kurumların sayısında artış sağlamakla kalmadı, aynı zamanda ETUC için de yeni bir rol oluşturdu. ETUC, üyeliğini ikiye katladığı ve temsil edilen işçi sayısının da buna bağlı olarak ikiye katlandığı için temsil gücü de artmıştır (Mitchell, 2014, s. 407-409).

ETUC'un temel kuruluş felsefesinde Avrupa'daki tüm işçilerin birincil temsilcisi olma arzusu yer almaktaydı ve Avrupa Birliğinde yaşanan bu büyük

1 Detaylı bilgi için: T.C. Avrupa Birliği Bakanlığı, "Bir Bakışta AB", (çevirimiçi), https://www.ab.gov.tr/ avrupa-birliginin-genislemesi_109.html, Erişim Tarihi: 15.05.2018. 
genişleme ETUC'un istediği ortamı oluşturmakta ve ilgi odağını yeni dahil olan ülkelere ve aday ülkelerdeki sendikaları bünyesine dahil etmek ve Avrupa'da işçi temsilciliği tekeli yaratmaya çalıştı. Çünkü gelecekteki üyelerin de bir an önce temsil edilmesi ETUC'a daha fazla işbirliği ortamı sağlayacak ve bunun için ön hazırlık aşamasını kolaylaştıracaktır. ETUC'un bu stratejisinin arka planında eski komünist yapıların yeniden canlanmasını engelleyen yeni sendika örgütlerini güçlendirmek ve bu örgütlerin istikrara kavuşturulmasını sağlamak yer almaktadır. Bu amaçla onlarla işbirliği başlattı ve sosyal diyalog, ortak ihaleler ve genel sosyal politikaya katılım konusunda eğitimler düzenledi. Aslında, bu gruplarla ilk temaslar 1989'da başlamış ve sonraki yıllarda yoğun bir şekilde genişletmiştir. ETUC'un Doğu Avrupa'ya doğru genişlemesi bazı olumsuz sonuçlara yol açmakta, özellikle konfederasyonun rolünü ve karakterini değiştirmektedir. Üye sayısındaki artışa bağlı olarak, içsel bölünmelerin ve örgütsel yapıdaki parçalanmanın artmasına yol açmaktadır (Taylor \& Mathers, 2004, s. 269-272). ETUC stratejisi, örgütlenme stratejisinden paydaşlık stratejisine doğru bir evrim geçirmektedir. Bu durum, AB'deki karar ve mevzuat süreçlerini etkileme firsatlarını artıracak, fakat aynı zamanda ETUC'un egemen yapısını sınırlandırması, kaynaklara erişimini zorlaştırması ve en önemlisi AB kurumlarına bağımlı hale gelmesine neden olacaktır. (Frege \& Kelly, 2003) Fakat ETUC'un son yıllarda gerçekleştirdiği eylemlerle de AB kurumlarını baskı altına almak ve sosyal sorunları ön plana çıkarıp bu yönde eylemlere girişmesini teşvik etmek istiyor. Bu noktada ETUC'un salt paydaş stratejisini izlemediği hala ilk yıllarında olduğu gibi örgütlenme stratejisine de belli noktalarda önem verdiğini göstermektedir (Taylor \& Mathers, 2004) (Gajewska, 2008). Ancak Hyman'a göre ETUC bu eylemleri gerçekleştirmesine rağmen daha radikal protesto eylemlerine karşı bir çekinceli yaklaşmaktadır (Hyman R. , 2013, s. 174). Ki bu durum AB ile olan paydaş ilişkisinin zarar görmemesi için çabası olarak ifade edilebilir.

ETUC son dönemde küreselleşmenin ortaya çıkardığı sorunlu alanlara da yönelmiştir. Bu da yeni bir kimlik arayışı içinde olduğu şeklinde yorumlanabilir. $\mathrm{Bu}$ doğrultuda temsil edilen ilgi alanlarının genişletilmesi, iklim ve enerji politikası, küresel ısınma, eko-verimlilik ve yenilenebilir enerji gibi sivil ve ekolojik konuların da ETUC'un örgütlenme programa dahil edilmesiyle yeni kimlik arayışı daha belirgin bir hal almıştır. ETUC bu süreçte STK'lar ile işbirliği ve sivil diyalogun teşvik edilmesi amacıyla geniş koalisyonlar oluşturmaya da gayret göstermektedir. Bu amacını da "küresel sorumluluğu 
üstlen demokrasiyi geliştir" şeklinde sloganlaştırmıştır. Dolayısı ile ETUC'un bölgesel bir güç olmaktan ziyade küresel sorunlu alanlara da yönelerek küresel bir güç olma hedefi içerisinde olduğu şeklinde yorumlanabilir. Ekolojik ve demokratik sorunların dahil edilmesi, ETUC'un klasik işçi ve işveren arasındaki çıkar çatışmasının ötesine geçmesine yardımcı olmaktadır. Bu durum yalnızca işçi dünyasının değil, tüm sorunlu kesimlerin çıkarlarının ve geniş koalisyonların yaratılmasının rolünü savunmayı mümkün kılmıştır. (Lambert, 2002, s. 189192) Dolayısı ile ETUC'un şimdiye kadar olan bölgesel rolünün dışına çıkmaya başladığ̣ söylenebilir. ETUC'un üstelendiği bu yeni rol ve bölgesel bir güç olmaktan küresel bir güç olmaya yönelmesi için şu üç hususa dikkat etmesi gerekir.

Birincisi Queux'in görüşüne göre, küreselleşme karşıtı hareket gerçekten de emek hareketlerinin yeniden canlandırılması için potansiyel bir kaynak ve itici güç sunsa bile bu bir seçenek değildir, ancak sendikalar ve sosyal taraflar için dikkatle düşünülmüş bir stratejiye gereksinim vardır. (Queux, 2005, s. 580583). Fakat ETUC'un bu amacını gerçekleştirebilmesi için Avrupa Birliğindeki diğer aktörlerin de desteğini alması gerekmektedir. Zira küreselleşme süreci ile birlikte tüm dünyada ve Avrupa' daki sendikalaşma oranlarının düşüş göstermesi ETUC'un da baskı gücünü zayıflatmaktadır. (Baccaro, 2008, s. 2)

İkincisi, ETUC'un tutarlı bir model oluşturma emellerini gerçekleştirebilmesi için üyeleri arasındaki çeşitliliği ve ideolojik farklılığ 1 dikkate alması gerekmektedir. Üyeleri arasında farklı gelenekleri, farklı endüstri ilişki türlerini ve sosyal diyalog türleri olan ülkeler bulunmaktadır. Bunların uyumlaştırılması konusundaki eğilimlerin eksikliğini ve hatta aralarındaki boşluğu gidermesi gerekmektedir. Zira üye sendikaların yapısı, yönetime katılma stratejileri, sosyal diyaloga katılma biçimler, işveren örgütleri ve hükümetler ile olan ilişkileri dikkate alındığında ETUC'un üye örgütlerin daha yakın işbirliğini önemli ölçüde başarabilmesi ve tutarlı bir Avrupa temsilcisi modelini küresel çapta geliştirmesini beklemek zordur. (Abbott, 1997, s. 467-468)

Üçüncüsü, Hymann'a göre ETUC görünenin aksine; ekonomik krizden beri (2008'den beri) AB karar verme sürecinde aslında çok etkisi olmadığ görülmektedir. AB kurumları ve ulusal hükümetler, kamu borçlarını en önemli öncelik olarak azaltmak için kemer sıkma önlemleri konusunda 1srar ettikleri için, işsizlik artış göstermiştir. Buna bağlı olarak ETUC tarafından ise işsizliği azaltıcı makroekonomik politikaların uygulanması ya da bu yönde bir eylem 
planı gerçekleştirilememiştir (Hyman R. , 2013, s. 173). 2012 yılında, ETUC ve ulusal sendikaların kemer sıkma politikalarına karşı yaptıkları protesto gösterilerine rağmen, Avrupa Konseyi (17 Avro ve altı Avro olmayan üye ülke) rekabetçi ücret baskılarını artıran mali kemer sıkma politikalarının güçlendirilmesine yol açan Euro Plus Paktı'nı onayladı. (Imig \& Tarrow, 2001)

ETUC, sosyal yardımlarda, kamu hizmetlerinde ve maaşlarda aşırı kesintileri reddeden Avrupa Yeni Anlaşması için kampanya başlatmıştır. ETUC, ücretlerin ekonominin motoru olduğunu ve artan gelir eşitsizliğini reddettiğini savunuyor. ETUC, ekonomik şokları çözmek ve dayanışmayı desteklemek için güçlü sosyal güvenlik ağlarını desteklemektedir. Konfederasyon, kamu maliyesi açıklarını düzeltmek için uzun vadeli bir yaklaşımı savunmakta ve vergi işlerinin önemli ölçüde değişmesini ve koordinasyonunu gerektirmektedir (ETUC, 2015).

\section{ETUC'un Yaşadığı Değişimin Uluslararası Sosyal Politikanın Değerleri Bağlamında Değerlendirilmesi}

Uluslararası sosyal politika ulusal düzeyde eşitlik, güvence (sosyal adalet) ve sosyal barışın sağlanmasında uluslararası ilke ve kurallar çerçevesindeki bir arayışı ifade etmektedir. Piyasa ekonomisi bireysel çıkarların önemi, artan rekabet, etkinlik verimlilik temeline dayanmaktadır. Piyasa ekonomisinin temel dayanakları 1980 sonrasında neoliberal politikaların etkisi ile birlikte devletin koruyucu rolünün azaltılması ve işgücü piyasalarını kuralsızlaştırılması yaklaşımlarının etkisi ile güçlenmiştir (Ulusoy, 2011, s. 246-247).

"Ekonomizm", siyasal tercihlerle insanı, ekonomik düzene ve işletmelerin rekabet gereklerine sıkı sıkıya bağlayan bir değerler sistemini ifade etmektedir. Uluslararası sosyal politikanın değerleri de bu yaklaşım çerçevesinde değerlendirilmelidir. Yeni liberal politikalar insanı sadece üretici ve tüketici olarak konumlandırmakta ve ekonomik büyümeyi tek amaç olarak kabul etmektedir (Erdut, 2002).

\section{Sosyal Adalet}

ILO'nun kuruluş amaçlarından biri olan sosyal adalet, küreselleşme sürecinin işçi ve işveren arasındaki eşitsizliğin ve güvencesizliğin önlenmesi için önemli bir değerdir. Bazı ülkelerde olumlu gelişmeler olsa da pek çok ülkede küreselleşmeye bağlı olarak sosyal hak ve özgürlüklerde uluslararası rekabet bahanesiyle gerilemeler yaşanmakta ve bu durum da sosyal adaletin değer 
haline gelmesine neden olan şartların ağırlaştı̆̆ını göstermektedir. Üstelik bu değer, günümüzde biçim değiştiren sosyal sorunların çözümü ve istikrar, barış ile güveni koruyabilmek için oldukça gereklidir. Sosyal adalet, sadece zayıf durumdakilere eşitlik ve güvence sağlamamakta, bununla birlikte insanlığın genel refahına da katk1 yapabilmektedir (Erdut, 2002). Nitekim ETUC Avrupa'daki çalışanların ve çalışanların ailelerinin insani, sivil, sosyal, istihdam haklarının ve yüksek yaşam kalitesi içinde birlikte barış içinde yaşamasını bir amaç olarak üstlenmiştir (ETUC, 2015). Bu bağlamda ETUC Avrupa sosyal diyaloğu içinde sosyal adalet vurgusunu ön plana çıararak temsil ettiği kişiler için daha iyi istihdam koşulları ve yaşam şartı oluşturmayı hedeflemektedir.

\section{Sosyal Barış}

Küreselleşme ile birlikte iki kutuplu dünya düzenin sona ermesiyle dünyaya ilişkin yeni bir bakış açısı ortaya çıkmıştır. Fakat devletin gerilemesiyle birlikte sınıf mücadelesi kendisini gerçekleştirecek ve yakın tarihte sınıf mücadelesi sona ermeyecektir. Çünkü, bir süre sonra devlet, "ekonomizm” kurallarına bağlı bir küresel sivil toplum için kendi ekonomik ve sosyal ayrıcalıklarını geri alacaktır. Üstelik bizzat devlet, bugünkü şiddeti unutturabilecek refah umudunun tek güvencesi konumundadır. Göreceli olarak yüksek gelir grubundaki insanların diğer insanlardan üstünlügüüü savunan yeni liberal görüş, benzer gerekçeler benzer sonuçları doğuracağından, geçmişte olduğu gibi yine hayal kırıklığına uğrayacaktır (Erdut, 2002).

$\mathrm{Bu}$ ideoloji ile birlikte derinleşen küreselleşme, ekonomik büyüme ve sosyal barışı tehdit eden eşitsizlikleri ortaya çıkarmaktadır. Daha öncede bahsedildiği üzere ETUC kurulduğu günden itibaren bölgesel seviyede sosyal barışı korumaya yönelik girişimlerde bulunduğu görülmektedir. Nitekim bunun en önemli örneğini süreç içerisinde yaşadığı değişim göstermektedir. ETUC Avrupa Birliği içindeki en önemli sosyal taraf olarak çalışma hayatındaki barışı sağlamaya yönelik hareket etmektedir.

ETUC, ITUC ve bölgesel diğer sosyal taraflarla dayanışma ve işbirliği içinde sosyal barışın korunması ve geliştirilmesine ilişkin yapıcı diyaloglar içindedir. Bunun en yakın örneğin 3-5 Mayıs 2017 tarihinde ITUC ve ETUC müşterek heyetinin Türkiye'ye gerçekleştirdiği ziyaretinde "Avrupa, Türkiye ve uluslararası toplum Türkiye'nin her yerinde barış, demokrasi, ekonomik kalkınma, eşitlik ve adil işi yaymak için çabalarını artırmalıdır” diyerek Türkiye'nin geçirmiş 
olduğu darbe girişiminin ardından oluşan olumsuz ortamın yerini yeniden sosyal barışa bırakması gerektiğini vurgulamıştır (ITUC C. I., 2017).

\section{Eşitlik}

Çalışanların çalışma ve yaşam koşullarının gelişmiş bir düzeyde denkleşmesi, ILO Anayasası'nın başlangıç bölümünde yer alan “eşit işe eşit ücret” ilkesi ile ortaya konulmuştur. Küreselleşme süreci bu eşitlik anlayışını değiştirmiş ve bireylerin çeşitliliğine vurgu yapmıştır. Buna bağlı olarak çalışma hayatında aynı veya benzer işi yapanlar arasında çeşitli ücret farklarının oluştuğu görülmektedir (Erdut, 2002). Zira ETUC Avrupa genelinde işçilerin ILO anayasasındakine benzer şekilde eşit işe eşit ücret ilkesi doğrultusunda hareket etmekte ve Avrupa Birliğinin kurumlarını bu yönde etkileme çabası içindedir. Aynı zamanda ETUC eşit işe eşit ücret, sosyal adalet ve güvenceli çalışma ekseninde Avrupa' da çeşitli eylemler gerçekleştirmektedir.

\section{Koruma}

Herkese iş ve gelir güvencesi sağlamak anlamını taşıyan koruma, bireylerin toplumla bütünleşmesinin yollarından birisidir. Bu yönüyle, koruma, insanın gereksinmeleri ile işletmenin gereksinmeleri arasında uygun bir bağ kurulmasını gerektirir.

İşçi ve işveren arasındaki asimetrik güç dengesi, bağımlı çalışma ilişkisinden kaynaklanmaktadır. Bu dengesizliğin giderilmesi ve çalışma yaşamında bireylerin korunması gerekmektedir. Günümüzde korumanın formu değişmiş ve istisnai tehlikelere karşı bireysel bir güvence olmaktan çıkmıştır. Artık belirsizliklerin önceden tahmin edilememesi ekseninde, her zaman ve her yerde ortaya çıkabilecek hale gelen bir rastlantıya karşı yeniden dizayn edilmesi gerekmektedir. $\mathrm{Bu}$ yüzden iş ve gelir güvencesinin tanımı içerisinde belirsizlik yönetiminin de yer alması zaruri hale gelmektedir.

Küreselleşme nedeniyle işletmelerin sürekli yeniden yapılanma ihtiyacı, Kuzey Amerika ve Avrupa'da olduğu gibi orta gelir düzeyine sahip birçok ülkede çok sayıda çalışanı etkilemekte, iş ve gelir güvencesini dikkate almayan düzenlemelerle karşılaşılmaktadır. Bu durum işgücü piyasası ve ekonominin genelinde uzun vadede istikrarsızlığa neden olabilecektir. Gerçekten de son zamanlarda, çalışanları, iş ve gelir güvencesinden yoksun bırakan esneklik gibi uygulamaların işletmeleri de olumsuz etkilediğine ilişkin araştırmalara 
rastlanmaktadır. İşletme yöneticileri, çalışan sayısının azaltılmasının güven duygusunu zedelemesinin yanında verimliliği de düşürdüğünü ifade etmektedirler. Bu yüzden, yeniden yapılanma süreci içinde hem insana özgü hem de işletme performansını dikkate alan, insani ve sosyal yönüne yeterince özen gösteren stratejiler geliştirilmesi, işletmelerin de kendi çıkarlarıyla uyumlu olacaktır (Erdut, 2002).

Bu bağlamda ETUC herhangi bir işgücü piyasası reformunun merkezi hedefini;

- İstikrarlı istihdam ilişkilerini teşvik etmek,

- Güvencesiz, düşük kaliteli, düşük ücretli işlerde ve geçici ve güvensiz işgücüne olan eğilimi durdurmak,

- Hayat boyu öğrenme, mesleki eğitim, niteliklerin geliştirilmesi gibi işçilerin güvencelerini artırabilecek önlemleri almak,

- İşletmelerde cinsiyet eşitliğini sağlamak,

- Sosyal diyalog ve toplu pazarlık sistemlerini güçlendirmek,

- İş dostu makroekonomik politikalarla yakın koordinasyon kurulması gerektiğini belirtmektedir. ETUC'a göre işçilerin istihdam güvencesi sorgulanmamalıdır (ETUC, 2007).

\section{Sonuç}

ETUC Avrupa düzeyindeki ulusal işçi hareketlerini koordine etme ve Avrupa'daki işçiler için tek bir ses oluşturma amacı taşımaktadır. Bu amacı gerçekleştirirken bölgesel bir güç olarak etkinliğini sürdürmektedir. ETUC'un Avrupa'da güçlü olmasının en temel nedeni ise konfederasyonun birleştirici özelliği ve Avrupa Birliği kurumlarını etkileme kapasitesinden kaynaklanmaktadır. ETUC, içinde bulunulan dönemin şartları gereğince değişikliklere ayak uydurma çabası içindedir. Küreselleşme süreci ulus devletlerin etkinliklerini ve bölgesel güçleri zayıflatmıştır. Bu bakımdan dünya genelinde bir değişim sürecinden bahsedilmektedir. Nitekim ETUC da bu değişim sürecinden payını almıştır. Zira ETUC'un kurulduğu ilk y1llarda sendikal örgütlenme bir bütünlük göstermektedir. Dolayısı ile bu dönemde bölgesel bir güç olabilmek adına konfederasyon içinde örgütlenme stratejisinin hakim olduğu görülmektedir. 
Küreselleşmenin etkinliğinin artması Avrupa’nın ekonomik, siyasi ve sosyal yapısının değişime uğraması ile yeni kurumlarla etkileşim kurmak salt örgütlenme stratejisi ile mümkün görülmemektedir. Zira örgütlenme stratejisinin temelinde mücadeleci yaklaşım hakimdir. ETUC bu süreçte üyelerinin çıkarlarını korumak ve geliştirmek adına örgütlenme stratejisinden paydaşlık stratejisine doğru bir yönelim göstermiştir.

ETUC Avrupa'da politik liderlik rolünü hedeflemektedir. Fakat örgütlenme stratejisini tamamen terk etmemesi ya da paydaş stratejiyi tamamen benimsememiş olması ETUC'un ulaşmak istediği hedeflere ulaşmasında bazı güçlüklerin ortaya çıkmasına neden olmaktadır. Bu sebeple ETUC üyesi olan sendikalar, üye sayıları itibariyle çok büyük bir potansiyele sahip olmasına rağmen Avrupa Sosyal Diyaloğu içinde hükümet ve işveren temsilcileri kadar etkin değildir.

Küreselleşme sürecinin sendikalar için getirdiği olumsuz ortamdan kısa vadede kurtulabilmek ve Avrupa sosyal diyaloğunda etkin olabilmek için benimsenen paydaşl1k stratejisi ETUC'u Avrupa kurumlarına ve bu kurumların sağladığı kaynaklara daha fazla bağımlı hale getirmektedir. Bundan dolayı son dönemlerde içinde bulunduğu uygunsuz ortamdan kurtulabilmek adına yeni birtakım girişimlerde bulunmaktadır. Bu girişimlerin en başında ise toplumun diğer güçsüz kalan kesimleri ile ittifak kurarak küresel bir sendikal harekete dönüşme çabası gelmektedir. ETUC'un hali hazırda Avrupa Birliği ve kurumları ile olan ilişkilerinde yürüttüğü paydaş strateji ile toplumsal seferberliği ön plana çıkardığı örgütlenme stratejisi birbiri ile uyumlu hale getirmeye çalışmaktadır. ETUC ilk günden beri mümkün olan en fazla üyeyi temsil etme ve siyasi bir güç olma amacını sürdürmektedir. Bu bakımdan sadece işçiler değil aynı zamanda sivil toplum örgütleri ve toplumun güçsüz kalan kesimlerini de harekete geçirmelidir. Kısaca son dönemde klasik endüstri ilişkilerinin öngördüğü çatışmacı stratejiyi biraz daha geri planda bırakarak çeşitli şekillerde aktif uzlaşmacı bir imaj çizmektedir. Bunun temel nedeni ise hiç şüphesiz küreselleşmenin getirmiş olduğu ortamda kendisine sağlam bir yer edinebilmektir.

Finansal Destek: Yazarlar bu çalışma için finansal destek almamışlardır. 


\section{Kaynakça/References}

Abbott, K. (1997). The European Trade Union Confederation: Its organization and objectives in transition. Journal of Common Market Studies, 35(3), 465-481.

Aguition, C. (2005). Bu dünya bizim. Başka Bir Küreselleşmenin Aktörleri. İstanbul: İthaki Yayınları.

Baccaro, L. (2008). Labour, globalization and Inequality: Are trade unions still redistributive? International Institute for Labour Studies, Discussion Paper.

Barchiesi, F. (2001). Transnational capital, urban globalisation and cross-border solidarity. Antipode, 33(1), 384-406.

Barnard, C. (2002). The Social Partners and the Governance Agenda. European Law Journal, 8(1), 80-101.

Bernaciak, M., Gumbrell- McCormick, R., \& Hyman, R. (2014). European Trade Unionism: From crisis tu renewal? Brussell: ETUI.

Bernaciak, M., Gumbrell-McCormick, R., \& Hyman, R. (2014). European Trade Unionism: From Crisis to Renewal? Brussels: ETUI.

Castells, M. (2010). The Rise of the Network Society. Malden: Wiley-Blackwell.

Ciampani, A., \& Tilly, P. (2017). The ETUC, National Unions and European Society: A Multilevel History. A. Ciampani, \& P. Tilly içinde, National Trade Unions and The ETUC: A History of Unity and Diversity (s. 13-16). Brussel: ETUI.

Comelo, A. F. (2007). Paving the Path Toward the Unionization of High-tech Sweatshops. V. Schmidt içinde, Trade Union Responses to Globalization (s. 51-62). Geneva: ILO.

Comission, E. (2018, 25 04). Consultations of the Social Partners. http://ec.europa.eu/ social $/$ main.jsp? catId $=522$ \&langId $=$ en, adresinden alındı.

Commission, E. (2018, 04 25). Employment, Social Affairs \& Inclusion. (çevrimiçi), http://ec.europa.eu/social/main.jsp?catId=329\&langId=en, Erişim Tarihi: 25.04.2018. adresinden alındı.

Çelikkaleli, B. (2012). Avrupa Birliği’nde Ekonomik Çıkarların Temsili ve Meşruiyet İlişkisi: Sosyal Taraflar Açısından Bir Değerlendirme. İzmir: D.E.Ü. Sosyal Bilimler Enstitüsü.

Daskalova, N., \& Tomew, L. (2007). Multinational Companies in Bulgaria: Impact on Labour Social Development. V. Schmidt içinde, Trade Unions Responses to Globalization (s. 73-83). Geneva: ILO.

D'Art, D., \& Turner, T. (2003). Independent collective representation: providing effectiveness, fairness, and democracy in the employment relationship. Employee Responsibilities and Rights Journal, 15(4), 169-181.

D'Art, D., \& Turner, T. (2007). Trade unions and political participation in the european union: Still providing a democratic dividend? British Journal of industrial Relations, 45(1), 103-136.

Ebbinghaus, B., \& Jelle Visser. (2000). The societies of Europe, Trade Unions in Western Europe since 1945. London: Palgrave Macmillan. 
Erdoğdu, S. (2003). Küresel sendikacılık. Küreselleşme Koşullarında Kapitalizm ve Sendikal Hareket, 253-288.

Erdoğdu, S. (2007). The Labour Platform: An alliance of trade unions in Turkey", ILO Publications. V. Schmidt içinde, Trade Union Responses to Globalization (s. 153-164). Geneva: ILO Publications.

Erdut, Z. (2002). Uluslararası sosyal politika ve Türkiye: Küreselleşme Bağlamında. İzmir: Dokuz Eylül Yayınları.

ETUC. (2015). ETUC Action Programme 2015-2019. Paris: ETUC.

ETUC. (2018, 05 18). ETUC, (çevrimiçi), https://www.ituc-csi.org/ituc-the-globaleconomic-and adresinden alınd 1

ETUC. (2018, 04 25). Aims and Priorities. https://www.etuc.org/aims-and-priorities adresinden alındı

ETUC. (2018, 04 26). European Trade Union Federations. https://www.etuc.org/en/page/ european-trade-union-federations-10-list-members adresinden alınd 1

ETUC. (2018, 04 25). Organization and People. https://www.etuc.org/aims-and-priorities adresinden alind 1

ETUC. (2018, 15 04). The European Social Dialogue. European Social Dialogue: https:// www.etuc.org/european-social-dialogue adresinden alınd 1

ETUC. (2018, 05 17). The London Declaration: A Call for Fairness and Tough Action https://www.etuc.org/en/statutorydocument/london-declaration-call-fairness-andtough-action adresinden alındı

ETUC. (2018,0425). The Treaty On The Functıonıng OfThe European Unıon., (çevrimiçi), http://eur-lex.europa.eu/legal-content/EN/TXT/PDF/?uri=CELEX:12012E/TXT, adresinden alind 1

Ferner, A., \& Hyman, R. (1992). Industrial Relations in the New Europe. Oxford: Blackwell Pub.

Fonow, M. M., \& Franzway, S. (2007). Transnational Union Networks, Feminism and Labour Advocacy. V. Schmidt içinde, Trade Union Responses to Globalization. Geneva: ILO.

Freeman, R. B., \& Medoff, J. L. (1984). What do Unions do? New York: Basic Books.

Frege, C., \& Kelly, J. (2003). Union revitalization strategies in comparative perspective. European Journal of Industrial Relations, 9(1), 7-24.

Gajewska, K. (2008). The emergence of a European labour protest movement? European Journal of Industrial Relations, 14(1), 104-121.

Gallin, D. (1994). Inside the new world order: Drawing the battle lines. New Politics, 107-132.

Gallin, D. (2000). Trade Unions and NGOs: A Necessary Partnership for Social Development. Geneva: United Nations Resarch Institute for Social Development.

Greenwood, J. (2011). Interest Representation in the European Union. London: Palgrave Macmillian. 
Hardy, J., \& Clark, N. (2007). Europan Union Enlargement, Workers and Migration: Implications for Trade Unions in the United Kingdom and Poland. V. Schmidt içinde, Trade Union Responses to Globalization (s. 125-138). Geneva: ILO.

Harvey, D. (2005). A brief histroy of neoliberalism. Oxford: Oxford University Press.

Hellman, M. (2007). Social Partnership at the Global Level: Building and Wood Workers' International Experiences with International Framework Agreements. V. Schmidt içinde, Trade Union Responses (s. 23-34). Geneva: ILO.

Hyman, R. (2001). European Integration and Industrial Relations: A Case of Variable Geometry? P. Waterman, \& J. Wills içinde, Place, Space and the New Labour Internationalisms (s. 164-180). Oxford: Balckwell Publishers.

Hyman, R. (2005). Trade Unions and the European social model. Economic and Industrial Democracy, 25(1), 9-40.

Hyman, R. (2013). European Trade Unions and the Long March Through the Institutions. P. Fairbrother, C. Levesque, \& M. Hennebert içinde, Transnational Trade Unionism: Building Union Power (s. 161-183). New York: Routledge.

ICFTU. (2001). A Trade Union Guide to Globalisation. Brussels: ICFTU Pub.

ICFTU. (2018). International Institute of Social History (ICFTU/ITUC Archives 19492009). Amsterdam: ICFTU Pub.

Imig, D., \& Tarrow, S. (2001). Contentious Europeans: Protest and Politics in an Emerging Polity. London: Rowman Littlefield Publishers.

Itschert, P., \& Bir, J. (2012). Corporate Social Responsibility- Union Thinking on the EU Strategy 2011-2014, Final Report ETUC. Brussels: ETUC.

ITUC. (2008). The Global Gender Pay Gap. Brussels: ITUC.

ITUC. (2018, 05 18). https://www.ituc-csi.org/IMG/pdf/gap-1.pdf adresinden alınd1

Kılıç, S. (2014). Endüstri İlişkileri Teorisi ve İnsan Kaynakları Yönetimi. Çalışma ve Toplum, 3(42), 111-136.

Keller, B., \& Sörries, B. (1999). The new European social dialogue: Old wine in new bottles? Journal of European Social Policy, 11-125.

Kirches, C. (2007). The European Trade Union Confederation Development and Role of a Bound Giant. Towards Transnational Trade Union Representation? National Trade Unions and European Integration (s. 1-16). Bochum: Institute for Social Movements.

Kloosterboer, D. (2007). Innovative Trade Union Strategies. Utrecht: FNV Marketing \& Communicate.

Koray, M., \& Çelik, A. (2007). Avrupa Birliği ve Türkiye'de Sosyal Diyalog. AB’ye Uyum Serisi. içinde Ankara: Belediye İş Sendikası.

Lambert, R. (2002). Labour Movement Renewal in the Era of Globalization: Union Responses in the South. J. Harrod, \& R. O’Brien içinde, Global Unions? (s. 185-204). London: Routledge. 
Lapeyre, J. (2015). European social dialogue: 30 years of experience and progress but what does the future hold? Policy Paper of Notre Europe (Jack Delors Institu, 124, $1-20$.

Martin, A., \& Ross, G. (2001). Trade Union Organizing at the European Level: The Dilemma of Borrowed Resources. D. Imig, \& S. Tarrow içinde, Contentious Europeans: Protest and Politics in an Emerging Polity (s. 53-76). Lanham: Rowman \& Littlefield Publishers.

Mitchell, K. (2014). The European Trade Union Confederation at 40: Integration and diversity in the European labor movement. Labor History, 55(4), 403-426.

Mittag, J. (2017). Flexible Adaptation Between Political, Social and Economic Intersts: The Multi-faceted Europeanisation of German Trade Unions. A. Ciampani, \& P. Tilly içinde, National Trade Unions and the ETUC: A History of Unity and Diversity (s. 1945). Brussels: ETUI.

Munck, R. (2003). Emeğin yeni dünyas1, küresel mücadele, küresel dayanışma. (M. Tekçe, Çev.), İstanbul: Kitap Yayınevi.

Parlak, Z. (2002). Avrupa Birliği’nde sosyal diyalog. M. Aykaç, \& Z. Parlak içinde, Tüm Yönleriyle Türkiye-AB İlişkileri. İstanbul: Elif Kitabevi.

Perez, M., \& Mc Donough, G. (2007). More Than Bananas: Social Responsibility Networks and Labour Relations in the Banana Industry in the Uraba Region of Colombia. V. Schmidt içinde, Trade Union responses to Globalization (s. 139-152). Geneva: ILO.

Phelan, C. (2007). Worldwide Trends and Prospects for Trade Union Revitalisation. C. P. vd., \& C. Phelan (Dü.) içinde, Trade Union Revitalisation: Trends and Prospects in 34 Countries (s. 1-11). Bern: Peter Lang.

Pollin, R. (2003). Countours of Descent: US economic Fractures and the Landscape of Global Austerity. New York: Verso Pub.

Queux, S. L. (2005). New protest movements and the revival of labour politics - a critical examination. European Review of Labour and Research, 569-588.

Radcliff, B. (2005). Class organization and subjective well-being: A cross-national analysis. Social Forces, 84(1), 513-530.

Robertson, R. (2000). Globalization social theory and global culture. London: SAGE Publications.

Robinson, W. (2009). Saskia sassen and the sociology of globalization: A critical appraisal. Sociological Analysis, 3(1), 5-29.

Ross, G., \& Martin, A. (1999). Through a Glass Darkly. A. M. vd. içinde, The Brave New World of European Labor (s. 368-397). New York: Berghahn.

Rowe, C. (2011). Regional representations in the EU: Between Diplomacy and Interest Mediation. London: Palgrave Macmillan.

Sassen, S. (2003). Globalization or denationalization. Review of International Political Economy, 10(1), 1-22. 
Scherer, C. (2007). Fredom of Association and Collective Barganing: The Practise of Multinational Companies in Brasil. V. Schmidt içinde, Trade Union Responses to Globalization (s. 85-96). Geneva: ILO.

Schmidt, E. (2007). Sustainability and a Unions: International Trade Union Action to Implement Sustainability Norms at Corporota Level. V. Schmidt içinde, Trade Union Responses to Globalization (s. 11-22). Geneva: ILO.

Schmidt, V. (2007). Trade Unions Responses to Globalization: A Review By The Global Union Research Network. (V. Schmidt, Dü.) Geneva: ILO.

Schmitter, P., \& Wolfgang, S. (1999). The Organization of Business Interests: Stduying the Associative Action of Business in Advanced Industrial Societies. MP1fG Discussion Paper.

Schulze, G., \& Ursprung, H. (1999). Globalisation of the economy and the Nation State. The World Economy, 22(3), 295-352.

Selamoğlu, A. (2003). İşçi sendikacılığında yeniden yapılanma ve örgütlenme modeli. Kocaeli Üniversitesi Sosyal Bilimler Enstitüsü Dergisi, 6(2), 63-98.

Taylor, G., \& Mathers, A. (2004). The European Trade Union Confederation at the Crossroads of Change? Traversing the Variable Geometry of European Trade Unionism. European Journal of Industrial Relations, 267-285.

Tokol, A. (2013). Endüstri İlişkileri ve Yeni Gelişmeler. Bursa: DORA Yayıncılık.

Tudway, R. (2007). Corporate Governance Reforms as a Means of Protecting and Promoting Worker Interests: Shaping the Corporation of Tomorrow. V. Schmidt içinde, Trade Union Responses to Globalization (s. 63-71). Geneva: ILO.

Turner, L. (1996). The Europeanization of labour- structure before action. European Journal of Industrial Relations, 325-345.

Turner, T., \& D'Art, D. (2012). Public perceptions of trade unions in countries of the european union: A causal analysis. Labor Studies Journal, 37(1), 33-55.

Ulusoy, Ü. H. (2011). Sosyal Hakların Korunması'nda Birleşmiş Milletler'in Rolü. Sosyal Haklar Uluslararası Sempozyumu III (s. 245-269). İstanbul: Petro-İş Yayını.

Visser, J. (2006). Union membership statistics in twenty-four countries. Monthly Labor Review, 129(1), 38-49.

Waddington, J. (2005). Trade Unions and the defence of the Europen social model. Industrial Relations Journal, 36(6), 518-540.

Waddington, J., \& Hoffman, R. (2000). Trade Unions In Europe: Facing Challenges and Searching for Solutions. J. Waddington, \& H. Reiner içinde, Trade Unions in Europe: Reform, Organisation and Restructuring (s. 27-79). Brussels: ETUI.

Welz, C. (2008). The European Social Dialogue Under Articles 138 and 139 of the EC Treaty (Actors, Processes, Outcomes). Nijmegen: Kluwer Law International Pub. 